\title{
A synoptic study of phytoplankton in the deep lakes south of the Alps (lakes Garda, Iseo, Como, Lugano and Maggiore)
}

\author{
Nico SALMASO*, Giuseppe MORABITO ${ }^{1)}$, Rosario MOSELLO ${ }^{1)}$, Letizia GARIBALDI $^{2}$, Marco SIMONA $^{3)}$, \\ Fabio BUZZI ${ }^{4)}$ and Delio RUGGIU ${ }^{1)}$
}

Dipartimento di Biologia, Università di Padova, Via U. Bassi, 58/B, I-35131 Padova, Italy

${ }^{1)}$ C.N.R. Istituto per lo Studio degli Ecosistemi, L.go Tonolli, 50, I-28922 Verbania Pallanza, Italy

${ }^{2)}$ Dipartimento Scienze Ambiente e Territorio, Università di Milano, Via Emanueli, 15, 20126 Milano, Italy

3) Sezione Protezione Aria, Acqua e Suolo, Riva Paradiso, 15, CH-6900 Lugano-Paradiso, Switzerland

4) ARPA Lombardia, Dipartimento di Lecco, Via I Maggio, 21/b, I-23848 Oggiono (LC), Italy

*e-mail corresponding author: nico.salmaso@unipd.it

\begin{abstract}
This paper presents a synoptic account of the most important results emerging from studies on the phytoplankton communities in the deep southern subalpine lakes Garda, Iseo, Como, Lugano and Maggiore (DSL) in the second half of the 1990s. At present, the trophogenic layers of these lakes are trophically different, ranging from the oligo-mesotrophy of lakes Maggiore and Garda to the meso-eutrophy of lakes Iseo and Lugano. The research confirmed the existence of a common pool of species developing in the DSL, as already suggested by early studies conducted on a seasonal basis from the end of the 1970s to the first half of the 1980s. However, multivariate analyses (Correspondence Analysis, CA, and a subsequent application of Non Metric Multidimensional Scaling) demonstrated that the species in this common pool were developing differently or exclusively along a geographic and a trophic gradient. The major differences in the geographic distribution were found between the easternmost lakes (Garda and Iseo) and those farthest to the West (Lugano and, partly, Maggiore), with intermediate characteristics in Lake Como. These differences were due mainly to changes in the dominance relationships and only secondarily to compositional changes. The detection of the ultimate causes of these differences should take into account other factors not considered in the paper (i.e. the specific analysis of the food webs, local climatic conditions, hydrology and seasonal input of nutrients). Despite the observed differences, common patterns in the sequence of seasonal assemblages in the DSL could be recognised and defined. The second gradient in the species distribution identified by CA was strongly correlated with the principal trophic descriptors (algal biomass and total phosphorus); this meant that the phytoplankton taxa could be ranked along a trophic spectrum, from oligotrophy to eutrophy. A brief examination of the main differences which have historically arisen with the progress of eutrophication in the DSL showed that the species identified in this study as being indicative of more eutrophic conditions were increasing in importance in some of the lakes.
\end{abstract}

Key words: phytoplankton, deep southern subalpine lakes, synoptic analyses, trophic gradients, multivariate analyses

\section{INTRODUCTION}

The ultimate aim of ecology is to study the interaction of organisms with their environment and the other organisms living in it (Wilson 1992; Krebs 2001). In phytoplankton studies this task has been essentially accomplished by two approaches, i.e. the ecophysiological and the comparative descriptive approaches (Sommer 1988). The first tries to attribute variations in distributional patterns to differences in the specific, experimentally determined growth requirements and resistance to mortality factors. The second approach, which is the most widely used by phytoplankton ecologists, attempts to find distributional patterns from abundances recorded in extended field surveys. The scientific basis and the meaning of the results produced by the two procedures are very different (Salmaso 2003).

A complete knowledge of the specific requirements for growth factors - an ideal, hypothetical condition would involve the complete characterization of the "fundamental niche" (sensu Hutchinson 1967). How- ever, even though laboratory experiments can add much to our knowledge of the physiological potentialities of particular algal species, rarely can they permit predictions of algal behaviour in the field (Ruggiu 2002). On the other hand, the results emerging from field surveys are an expression of the "realised niche", i.e. the reduced hypervolume in which a species exists as a consequence of competition and limitation by other factors, corresponding to the resources effectively used by a species. The capacity for colonisation, growth and resistance to mortality factors in response to the most important environmental axes (defined by the fundamental niche) is strongly reduced both by environmental constraints typical of the colonised lakes (including climatic and meteorological factors), and by competition dynamics. The relative importance of these two sets of factors in lakes of different trophic status are still the object of discussion (e.g., Harris 1994). This underlines the necessity to consider more abiotic and biotic factors, or classes of factors, in the study of species distribution in different types of lakes. Many discrepancies and the 
lack of unifying concepts in studies of the distribution of phytoplankton along trophic gradients originated from the implicit reductive assumption of the existence of selective factors acting almost exclusively along a unique environmental axis (Salmaso 2003). In fact, lakes with the same trophic status, but with different morphometric and hydrological properties, rarely develop the same algal assemblages, nor they will react in a similar way to changes in nutrient loads. Practical examples are the high flushed meso-eutrophic reservoirs in NE-Italy, where the research carried out during the 1990s documented an almost complete absence of pelagic cyanobacteria (e.g., Moccia et al. 2000), which are considered a common sign of eutrophication (Watson et al. 1997), but extremely susceptible to decreasing stability of the water column (Reynolds 1997; Reynolds et al. 2002). At the other extreme of the hydrological gradient, significant differences were recognised in the phytoplankton composition and abundance in a group of "large lakes" located at different latitudes and climatic regions (Pollingher 1990).

The large, deep lakes located south of the Alps share many common physiographic characteristics, which could have a significant influence on the selection of common phytoplankton populations; although limited in their scope and available material, the few comprehensive papers published on this topic seem to confirm this assumption (see section 2). In our study, the hypothesis to be confirmed is that the great depth and climatic location of the deep southern subalpine lakes constitute a sort of standardising factor, directing the rearrangement of the seasonal assemblages towards a limited number of scenarios in response to changes in trophic status (cf. Ruggiu \& Mosello 1984; Salmaso 2000). This assumption implies that lake districts with different physiographic and climatic characteristics will exhibit their own associations, even in the presence of comparable trophic levels (Ruggiu 2002).

This paper concludes a concerted series of contributions on the phytoplankton ecology of the southern subalpine lakes (from E to W) Garda (Salmaso 2002), Iseo (Garibaldi et al. 2003), Como (Buzzi 2002), Lugano (Simona 2003) and Maggiore (Morabito et al. 2002). Its main objectives are: i) to ascertain whether common patterns exist in the recent distribution and abundance of the dominant phytoplankton species in the deep southern subalpine lakes; ii) if this is the case, to interpret the differences in abundance and/or composition on the basis of the chemical (including nutrient content), physiographic and hydrological characteristics of the single lakes; and iii) to provide indications about the trophic range covered by the most important phytoplankters in this peculiar typology of lakes.

\section{STUDY SITES AND PREVIOUS STUDIES}

The geographical location and morphometric characteristics of the deep southern subalpine lakes (DSL) considered in this research are reported in figure 1 . In this group of lakes, the largest is Lake Garda $(\mathrm{V}=49$ $\left.\mathrm{km}^{3} ; \mathrm{S}=368 \mathrm{~km}^{2}\right)$, followed by Lago Maggiore $(\mathrm{V}=38$ $\left.\mathrm{km}^{3} ; \mathrm{S}=213 \mathrm{~km}^{2}\right)$, Como $\left(\mathrm{V}=23 \mathrm{~km}^{3} ; \mathrm{S}=146 \mathrm{~km}^{2}\right)$ and Iseo $\left(\mathrm{V}=7.6 \mathrm{~km}^{3} ; \mathrm{S}=62 \mathrm{~km}^{2}\right)$. Among the DSL, Lake Lugano stands out for its subdivision into three basins (Barbieri \& Polli 1992); the northern basin which was included in this research - is the largest of the three $\left(\mathrm{V}=4.7 \mathrm{~km}^{3} ; \mathrm{S}=28 \mathrm{~km}^{2}\right)$. The maximum depths of these lakes range from $251 \mathrm{~m}$ (Lake Iseo) to 410 m (Lake Como).

The DSL present some common morphological features (Ambrosetti \& Barbanti 1997). They are narrow, elongated and delimited laterally by steep sides; their bottom is generally flat. Their thalwegs are roughly North-South oriented, with the exception of the N-basin of Lake Lugano (East-West).

The watersheds of lakes Garda and Iseo are mainly composed of sedimentary rocks; crystalline formations (including both igneous and metamorphic rocks) are present only in the most northerly sections. Similarly, the drainage basin of Lake Lugano is dominated by calcareous rocks (limestones and dolomites), with outcrops of quarziferous porphyries and metamorphic rocks. The northern and southern parts of the watershed of Lake Como are mainly composed of igneous and sedimentary rocks, respectively. The northern and western drainage basin of Lago Maggiore is composed of metamorphic and igneous rocks; calcareous rocks are present only in the eastern part of the watershed (Vollenweider 1965; Bonomi et al. 1979).

The DSL lie within the River Po catchment area, and contribute water for about $40 \%$ of its discharge. Their theoretical renewal times are around 4-5 years (lakes Maggiore, Como and Iseo), 12 years (Lake Lugano, Nbasin) and 27 years (Lake Garda). Compared with the other lakes considered, the longer water renewal time of Lake Garda is due to its low catchment/lake surface ratio and to lower annual rainfall.

During the 1990s, the DSL were the object of numerous studies centred on the quality of lake waters and eutrophication. Besides the series of papers edited by Mosello \& Giussani (1997) and de Bernardi et al. (2000), other studies concerned limnological investigations carried out in Lake Garda (Salmaso et al. 1997, 2001a, 2002; Salmaso \& Decet 1998), Lake Iseo (Garibaldi et al. 1995, 1999), Lake Como (Mosello et al. 1991, 1999, 2001), Lake Lugano (Barbieri \& Polli 1992; Barbieri \& Mosello 1992; Barbieri \& Simona 2001) and Lago Maggiore (Manca et al. 1992; de Bernardi et al. 1996; Morabito \& Pugnetti 2001).

Several papers on phytoplankton ecology appeared in the same period, and some of them touched on historical aspects, e.g. those edited by Mosello \& Giussani (1997) and those published in the frame of this project (Buzzi 2002; Morabito et al. 2002; Salmaso 2002; Garibaldi et al. 2003; Simona 2003). However, papers of a 


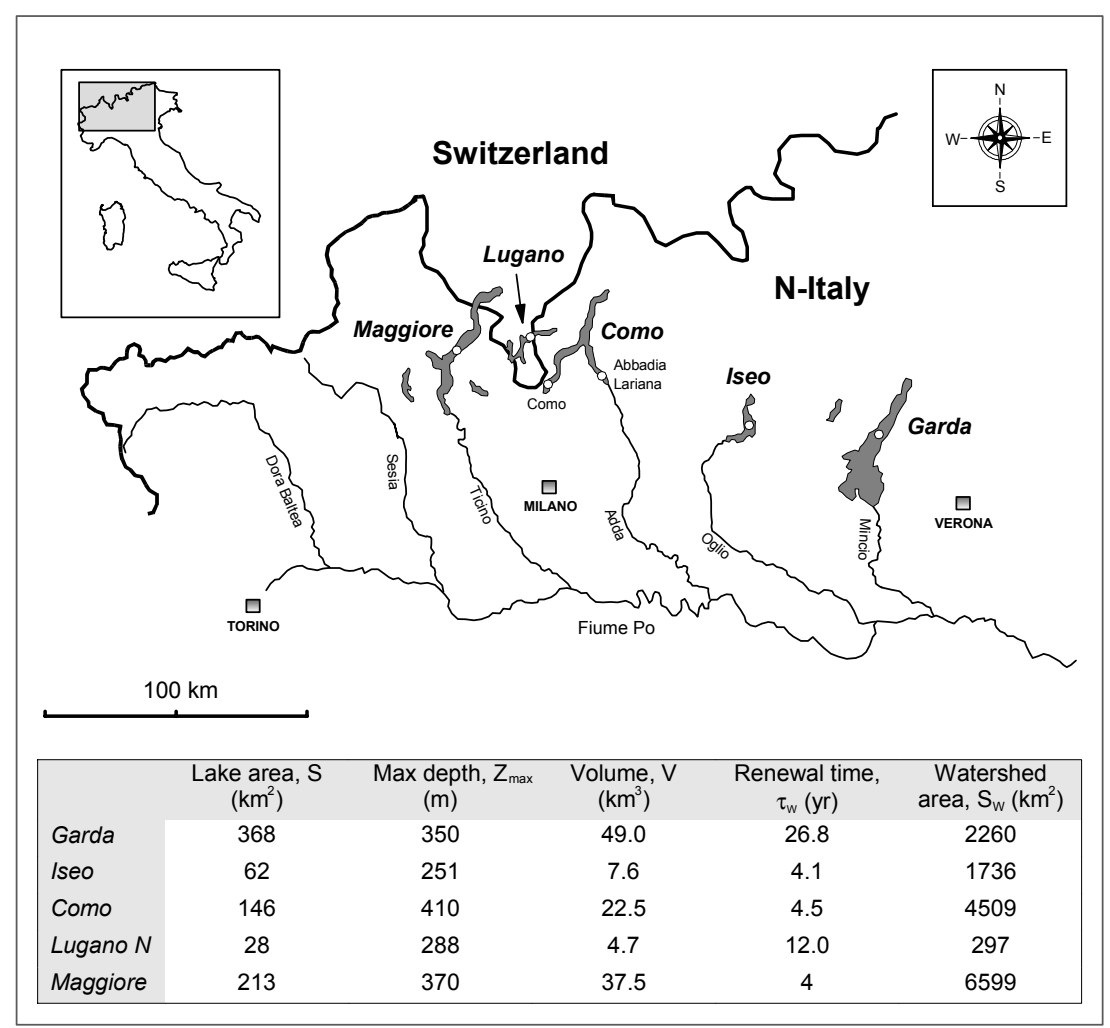

Fig. 1. Geographical location and morphometric characteristics of the deep southern subalpine lakes (DSL) in Northern Italy (data from Ambrosetti \& Barbanti 1992). The hollow circles indicate the location of the six sampling stations.

comprehensive nature are very rare, and are limited to selected temporal periods of the annual cycle, or discuss only some aspects of the phytoplankton communities. Ruggiu (1983) and Ruggiu \& Mosello (1984) described the phytoplankton characteristics of the largest lakes south of the Alps based on samples collected at the time of the deepest mixing (early spring) and at the end of the stratification period (October-November). These works showed that the same group of species was present in the phytoplankton communities of the studied lakes, which had quite different trophic conditions, and consequently showed a wide range of biomass and production values. Reviewing the literature published during the 1990s, Salmaso (2000) recognised the existence of the same dominant functional groups of chlorophytes and cyanobacteria in the DSL, with increasing importance of Oscillatoriales (Planktolyngbya limnetica and Planktothrix rubescens) and Chlorococcales in the meso- and eutrophic lakes.

\section{METHODS}

Details of the methods used for limnological investigations, chemical analyses and phytoplankton determinations are reported in the papers published in the frame of this project, namely Buzzi (2002), Morabito et al. (2002), Salmaso (2002) Garibaldi et al. (2003), and Simona (2003); these papers will be collectively referred to below as "DSL papers".
The data used in this work are essentially those reported in this set of papers, with few original integrations. Further information on the seasonal development of phytoplankton in lakes Garda and Maggiore during the years analysed in this work was reported in Salmaso (2003) and Morabito et al. (2003), respectively. Except where otherwise stated, the data refer to monthly samples collected in the layer between 0 and $20 \mathrm{~m}$. The field work and samplings refer to the periods 1997-1999 (Maggiore), September 1997-August 1999 (Como) and 1998-2000 (Garda, Iseo and Lugano). The research was carried out at single stations located at the deepest point of each lake, with the exception of Lake Como, where the field work was performed at two stations representative of the $\mathrm{W}$ and $\mathrm{E}$ branches (Como, $\mathrm{Z}_{\max }=100 \mathrm{~m}$, and Abbadia Lariana, $Z_{\max }=135 \mathrm{~m}$ ) (Fig. 1).

An effort was made to characterise each lake with a series of variables of a synthetic nature, evaluated at significant moments in the year or as averages in time, or as peak values and in different depth ranges. All of them, and the values for the respective lakes, are reported in table 1 . The computations were carried out for every lake and every year, with the exception of the two Lake Como stations, for which the study period (September 1997-August 1999) was considered as a whole. To highlight the similarities among the different lakes on the basis of synthetic groups of variables, the single cases (the six stations considered for the different years or periods, for a total of 14 cases; cf. table 1) were or- 
Tab. 1. Principal chemical, physical and biological characteristics of the deep southern subalpine lakes (DSL). Except where otherwise stated, the computations refer to the epilimnetic layer $0-20 \mathrm{~m}$ and to the indicated years or periods. $\mathrm{TP}_{\text {lake, }}$, average concentrations of total phosphorus (TP) measured at spring overturn in the whole water column; $\mathrm{TP}_{\mathrm{MaxSp}}$, maximum spring concentrations of $\mathrm{TP} ; \mathrm{TP}_{\text {avg }}$, annual average concentrations of $\mathrm{TP}$. The remaining parameters report the annual averages and maximum concentrations of chlorophyll- $a\left(\mathrm{Chl}_{\text {avg }}, \mathrm{Chl}_{\max }\right)$ and $\mathrm{pH}\left(\mathrm{pH}_{\mathrm{avg}}, \mathrm{pH}_{\max }\right)$, the annual averages and minimum values of transparency $\left(\mathrm{Z}_{\mathrm{S} \_ \text {avg }}, \mathrm{Z}_{\mathrm{S}_{-} \min }\right)$, nitrate nitrogen $\left(\mathrm{NO}_{3}-\mathrm{N}_{\text {avg }}, \mathrm{NO}_{3}-\mathrm{N}_{\min }\right)$, reactive silica $\left(\mathrm{Si}_{\text {avg }}, \mathrm{Si}_{\text {min }}\right)$, alkalinity $\left(\mathrm{Alk}_{\text {avg }}, \mathrm{Alk}_{\mathrm{min}}\right)$ and conductivity at $20{ }^{\circ} \mathrm{C}\left(\mathrm{Cond}_{\mathrm{avg}}\right.$, Cond $\left.\mathrm{min}_{\mathrm{m}}\right)$, and the annual average values of phytoplankton biovolume $\left(\mathrm{Biov}_{\mathrm{avg}}\right){ }^{(1)} \mathrm{In}$ Lake Como the computations of $\mathrm{TP}_{\text {lake }}$ and $\mathrm{TP}_{\mathrm{MaxSp}}$ refer to average values representative of two spring periods (1998 and 1999); ${ }^{(2)}$ In Lake Iseo the chlorophyll- $a$ and phytoplankton samples were collected in the 0-10 m layers.

\begin{tabular}{|c|c|c|c|c|c|c|c|c|c|c|c|c|c|c|}
\hline & \multicolumn{3}{|c|}{ Garda } & \multicolumn{3}{|c|}{ Iseo } & \multicolumn{2}{|c|}{$\begin{array}{c}\text { Como } \\
\text { Abb.L. Como } \\
\end{array}$} & \multicolumn{3}{|c|}{ Lugano } & \multicolumn{3}{|c|}{ Maggiore } \\
\hline & 1998 & 1999 & 2000 & 1998 & 1999 & 2000 & $\begin{array}{l}\text { IX/97- } \\
\text { VIII/99 }\end{array}$ & $\begin{array}{l}\text { IX/97- } \\
\text { VIII/99 }\end{array}$ & 1998 & 1999 & 2000 & 1997 & 1998 & 1999 \\
\hline $\mathrm{TP}_{\text {lake }}^{(1)}\left(\mu \mathrm{g} \mathrm{P}^{-1}\right)$ & 20 & 21 & 19 & 66 & 68 & 62 & 36 & 38 & 172 & 172 & 148 & 10 & 12 & 11 \\
\hline $\mathrm{TP}_{\mathrm{avg}}\left(\mu \mathrm{g} \mathrm{P} \mathrm{^{-1 } )}\right.$ & 9 & 12 & 11 & 11 & 21 & 21 & 16 & 27 & 12 & 25 & 39 & 9 & 9 & 10 \\
\hline $\mathrm{TP}_{\mathrm{MaxSp}}{ }^{(1)}\left(\mu \mathrm{g} \mathrm{P}^{-1}\right)$ & 13 & 21 & 17 & 22 & 46 & 45 & 35 & 41 & 22 & 56 & 67 & - & - & - \\
\hline $\mathrm{Chl}_{\mathrm{avg}}^{(2)}\left(\mu \mathrm{g} \mathrm{l}^{-1}\right)$ & 3.1 & 3.7 & 4.1 & 5.9 & 6.3 & 8.3 & 3.9 & 3.7 & 6.5 & 7.5 & 8.7 & 3.7 & 3.4 & 2.9 \\
\hline $\mathrm{Chl}_{\max }{ }^{(2)}\left(\mu \mathrm{g} \mathrm{l}^{-1}\right)$ & 4.4 & 7.7 & 9.3 & 14.0 & 15.0 & 32.0 & 8.4 & 9.7 & 13.0 & 25.1 & 23.4 & 9.5 & 6.2 & 5.6 \\
\hline $\mathrm{Z}_{\mathrm{S}_{\mathrm{a} a v g}}(\mathrm{~m})$ & 10.6 & 10.4 & 7.2 & 6.2 & 5.3 & 4.9 & 7.8 & 6.2 & 8.1 & 5.5 & 6.3 & 6.3 & 7.1 & 7.5 \\
\hline $\mathrm{Z}_{\mathrm{S}-\min }(\mathrm{m})$ & 6.0 & 3.5 & 3.5 & 2.7 & 2.8 & 2.4 & 3.5 & 1.5 & 3.3 & 2.5 & 2.8 & 2.5 & 2.5 & 2.0 \\
\hline $\mathrm{NO}_{3}-\mathrm{N}_{\text {avg }}\left(\mu \mathrm{g} \mathrm{N} \mathrm{1}^{-1}\right)$ & 233 & 200 & 193 & 723 & 585 & 575 & 706 & 824 & 430 & 340 & 370 & 677 & 765 & 747 \\
\hline $\mathrm{NO}_{3}-\mathrm{N}_{\min }\left(\mu \mathrm{g} \mathrm{N}^{-1}\right)$ & 171 & 58 & 53 & 629 & 453 & 472 & 482 & 464 & 330 & 170 & 230 & 573 & 679 & 612 \\
\hline $\mathrm{Si}_{\text {avg }}\left(\mathrm{mg} \mathrm{Si} \mathrm{l}^{-1}\right)$ & 0.42 & 0.53 & 0.37 & 0.44 & 0.75 & 0.81 & 0.66 & 0.64 & 0.27 & 0.38 & 0.54 & 1.07 & 0.96 & 1.07 \\
\hline $\mathrm{Si}_{\min }\left(\operatorname{mg~Si} 1^{-1}\right)$ & 0.22 & 0.26 & 0.16 & 0.07 & 0.21 & 0.12 & 0.08 & 0.14 & 0.11 & 0.13 & 0.14 & 0.88 & 0.59 & 0.44 \\
\hline $\mathrm{Alk}_{\mathrm{avg}}\left(\mathrm{meq} \mathrm{l}^{-1}\right)$ & 2.00 & 2.03 & 2.04 & 1.69 & 1.70 & 1.64 & 1.21 & 1.21 & 1.95 & 2.01 & 1.99 & 0.74 & 0.74 & 0.75 \\
\hline $\operatorname{Alk}_{\min }\left(\operatorname{meq~} 1^{-1}\right)$ & 1.88 & 1.90 & 1.91 & 1.31 & 1.33 & 1.24 & 1.10 & 1.08 & 1.64 & 1.77 & 1.75 & 0.69 & 0.67 & 0.67 \\
\hline $\operatorname{Cond}_{\mathrm{avg}}\left(\mu \mathrm{S} \mathrm{cm}^{-1}\right)$ & 208 & 209 & 209 & 250 & 250 & 242 & 161 & 183 & 203 & 208 & 211 & 136 & 136 & 140 \\
\hline $\operatorname{Cond}_{\min }\left(\mu \mathrm{S} \mathrm{cm}^{-1}\right)$ & 198 & 196 & 195 & 229 & 225 & 193 & 145 & 169 & 176 & 188 & 184 & 127 & 124 & 123 \\
\hline $\mathrm{pH}_{\text {avg }}$ & 8.33 & 8.26 & 8.35 & 8.34 & 8.11 & 8.19 & 8.03 & 7.90 & 8.14 & 8.09 & 8.10 & 8.04 & 7.79 & 7.70 \\
\hline $\mathrm{pH}_{\max }$ & 8.66 & 8.59 & 8.62 & 8.79 & 8.37 & 8.53 & 8.75 & 8.85 & 8.37 & 8.41 & 8.30 & 8.62 & 8.19 & 8.37 \\
\hline $\operatorname{Biov}_{\text {avg }}^{(2)}\left(\mathrm{mm}^{3} \mathrm{~m}^{-3}\right)$ & 845 & 1059 & 1103 & 2629 & 3469 & 2600 & 792 & 1053 & 848 & 1454 & 1226 & 1157 & 730 & 918 \\
\hline
\end{tabular}

dered by Principal Components Analysis calculated from the correlation matrix obtained from selected subsets of the environmental and biotic variables, followed by orthogonal rotation (varimax method, Stenson \& Wilkinson 2002).

Unlike the data reported in the DSL paper (Salmaso 2002), to make it easier to compare the water transparency in the five lakes, the Secchi disk values for Lake Garda considered in this work refer to readings made without bathyscope. In any case, for this lake and for the period 1998-2000, the readings made with $\left(Z_{\text {bat }}\right)$ and without $\left(Z_{S}\right)$ the bathyscope were strongly related to each other $\left(Z_{\text {bat }}=1.174 Z_{S}-0.134 ; r^{2}=0.98, n=37\right)$.

The phytoplankton communities of the five lakes were compared considering - for every station and period - the biovolume peaks of the single taxa. Of these, only those reaching biovolume peaks greater than 100 $\mathrm{mm}^{3} \mathrm{~m}^{-3}$ at least in one year (or in the whole study period in Lake Como) were considered in the analyses. The use of this "dominance based" criterion reduces the risk of spurious results due to the inclusion of rare, occasional, or poorly determined species.

As a preliminary step, the species datasets from the five lakes were checked out for taxonomical comparability. In the case of the same species classified within different taxonomical categories, and in the case of selected closely related species or genera, the species were merged in one group of organisms (taxon). In particular, this was the case with Aphanothece spp. and Aphanocapsa spp., Limnotrichoideae (Limnothrix-like colonies and Limnothrix redekei; Anagnostidis \& Komárek 1988), Aulacoseira spp. (A. granulata and A. ambigua), small centric diatoms (mainly Cyclotella spp., followed by Stephanocostis sp. and Thalassiosira sp.), Tabellaria spp. (T. fenestrata and T. flocculosa), Snowella spp. (including $S$. cf. aracnoidea and colonies ascribed to Coelosphaerium or Snowella, i.e., colonies with the cytoplasmatic radial stalks apparently absent or difficult to identify) (cf. Komárek \& Anagnostidis 1999). Hereafter, the filaments of the Planktothrix rubescens/agardhii group (cf. Humbert \& Le Berre 2001), will be reported as $P$. rubescens/ag.

The matrix of the single 14 cases (one column per year or period of observation for each lake) against biovolume peaks was examined using Correspondence Analysis (CA); before computation, the data were logtransformed $\left(\mathrm{Y}_{\mathrm{i}}=\log \left(\mathrm{X}_{\mathrm{i}}+1\right)\right)$ to reduce the weight of the most abundant taxa. The simultaneous ordinations of the lakes and species obtained by CA were compared with those obtained by applying Non Metric Multimensional Scaling (NMDS), following the methods described in Salmaso (1996, 2002). Axes I and II of the lakes and species ordinations obtained by $\mathrm{CA}$ and NMDS were compared by parametric and non-parametric correlations. As in NMDS the orientation of the axes is arbitrary, the configurations were rotated and trans- 


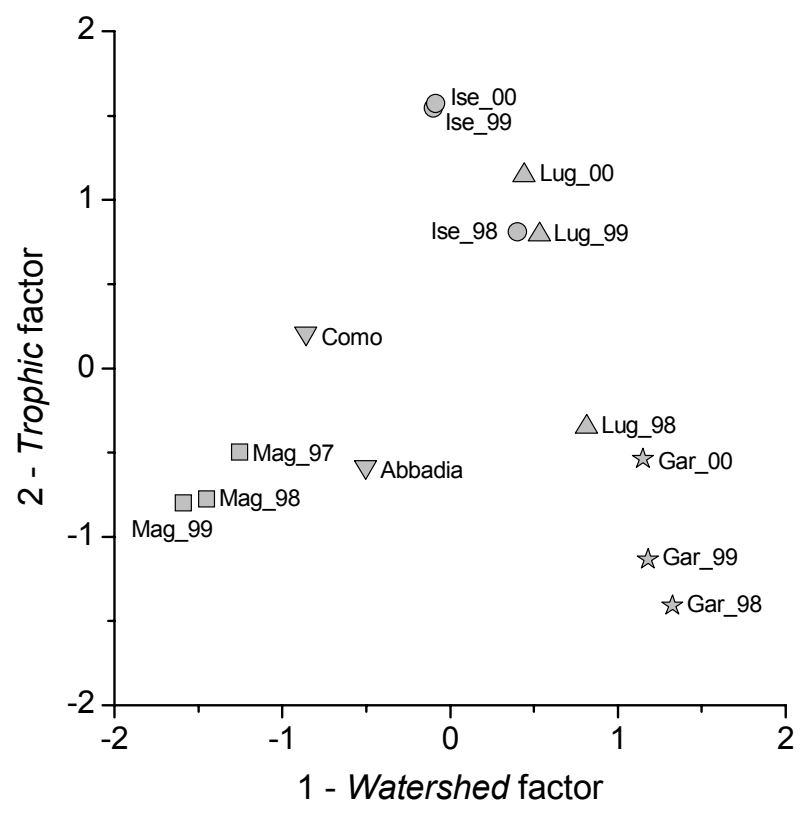

Fig. 2. Ordination of the DSL by principal components analysis with varimax rotation. The single lakes have been coded using the first three letters of the name (Gar, Garda; Ise, Iseo; Lug, Lugano; Mag, Maggiore) and the studied years; the two stations of Lake Como have been written in full. The five lakes are marked with different symbols. The component loadings are reported in table 2.

posed before the comparisons to maximise their fit with the corresponding CA-ordinations by orthogonal Procrustes rotation. Multivariate analyses were carried out using Statistica and Systat packages (StatSoft 1997; Systat 2002).

\section{RESULTS AND DISCUSSION}

\subsection{Trophic characterisation}

The variables computed for the five lakes (ordered from $\mathrm{E}$ to $\mathrm{W}$ ) are reported in table 1. Detailed comments on the seasonal evolution of these variables in the single lakes may be found in the DSL papers (section 3).

The average epilimnetic concentrations of TP and chlorophyll- $a$, the average values of Secchi disk depth, the maximum concentrations of chlorophyll- $a$ and the minimum values of the Secchi disk depth were used as in OECD (1982) to estimate the trophic status of the five lakes in the different study periods. Lakes Maggiore and Garda are oligo-mesotrophic, the two stations of Lake Como are meso-oligotrophic (AbbadiaL.) and mesotrophic (Como), whereas lakes Iseo and Lugano are meso-eutrophic.

The inclusion of some of these lakes in broad trophic categories reflects the existence of significant differences in the development of the algal biomass in the different years. In particular, the observations made on lakes Garda, Iseo and Lugano in the period 1998-2000 showed a greater replenishment of TP during the spring mixing in 1999 and 2000 (Tab. 1, TP $\mathrm{MaxSp}_{\mathrm{M}}$ ), with a corresponding increase in algal biomass. The higher replenishment of TP in these two years occurred after two harsh winters, which caused a deep overturn in lakes
Iseo and Lugano (Garibaldi et al. 2003; Simona 2003) and a complete overturn in Lake Garda (Salmaso 2002). More in general, the synchronisms in the year to year changes in the trophic status of these three lakes originated from the common effects of the evolution of winter climatic conditions on the subalpine region (Salmaso et al. 2003; Simona 2003). The phosphorus replenishment was greater in the two meromictic lakes Iseo and Lugano, because of the greater differences in the phosphorus content in the trophogenic and hypolimnetic layers.

In contrast to the above cases, the interannual variations of the algal crop in Lago Maggiore seem dependent rather on meteorological conditions occurring over short timescales than on climatic evolution (Morabito 2001). The vertical distribution of TP in Lago Maggiore is fairly homogeneous (compare $\mathrm{TP}_{\text {lake }}$ and $\mathrm{TP}_{\mathrm{avg}}$, Tab. 1 ), so that the impact of a complete or greater overturn triggered by harsh winters is strongly minimised or poorly detectable (cf. Manca et al. 2000). In Lake Como, the shorter study period and the location of the two stations in the shallow zones of the $\mathrm{W}$ and $\mathrm{E}$ basins (100 and $135 \mathrm{~m}$, respectively) make it impossible to assess the effects of overturn on the trophic status. However, data collected in the spring months in the deepest station of Lake Como $\left(Z_{\max }=410 \mathrm{~m}\right)$ during the last decade showed differences in the vertical distribution of $\mathrm{TP}$, suggesting that this lake may be susceptible to deep mixing events. The higher trophic conditions recorded at the station of Como are due to its location in the rather closed $\mathrm{W}$ basin, separated as it is from the rest of the lake by an underwater ridge, devoid of effluents and subject to high anthropogenic pressure (Mosello et al. 1991). 


\subsection{Synthetic analysis of the environmental and biotic variables}

The results of the ordination of the individual cases of Table 1 by PCA and varimax rotation are reported in figure 2 and table 2 . To simplify the presentation of the data, the computation was based only on the annual epilimnetic averages of TP, chlorophyll- $a$, nitrate, reactive silica, alkalinity, conductivity, $\mathrm{pH}$ and biovolume; transparency $\left(Z_{\mathrm{S} \text { avg }}\right)$ was also considered. The inclusion of the remaining variables (minimum or maximum values) computed for the epilimnetic layers does not change the general conclusions, as significant correlations $(0.73<r<0.97, P<0.01)$ exist between these variates and their corresponding average values, with the exception of the nonsignificant relationship between $\mathrm{pH}_{\text {avg }}$ and $\mathrm{pH}_{\max }(r=0.39, P>0.05)$. A two-factor solution explaining around $78 \%$ of the total variance was computed (Tab. 2). In addition to the large proportion of the explained variance, this solution was chosen because it yielded the most straightforward interpretation without loss of significant information.

Tab. 2. Principal components analysis with varimax rotation: percentage of explained variance and correlations between the first two factors and the input variables. The significant correlations are reported in bold $(P<0.01)$ and italics $(P<0.05)$. Variables are abbreviated as in table 1 .

\begin{tabular}{lcc}
\hline Factor & $\mathrm{I}$ & $\mathrm{II}$ \\
\hline Variance explained & $44.2 \%$ & $33.4 \%$ \\
$\mathrm{Alk}_{\text {avg }}$ & $\mathbf{0 . 9 6}$ & 0.23 \\
$\mathrm{pH}_{\text {avg }}$ & $\mathbf{0 . 8 8}$ & 0.11 \\
$\mathrm{Cond}_{\text {avg }}$ & $\mathbf{0 . 6 9}$ & 0.63 \\
$\mathrm{Si}_{\text {avg }}$ & $\mathbf{- 0 . 8 8}$ & -0.05 \\
$\mathrm{NO}_{3} \mathrm{~N}_{\text {avg }}$ & $\mathbf{- 0 . 8 7}$ & 0.18 \\
$\mathrm{Chl}_{\text {avg }}$ & 0.31 & $\mathbf{0 . 8 5}$ \\
$\mathrm{Biov}_{\text {avg }}$ & 0.08 & $\mathbf{0 . 8 0}$ \\
$\mathrm{TP}_{\text {avg }}$ & 0.07 & $\mathbf{0 . 6 8}$ \\
$\mathrm{Z}_{\mathrm{S}_{-} \text {avg }}$ & 0.41 & $\mathbf{- 0 . 8 4}$ \\
\hline
\end{tabular}

The first factor has the highest positive loadings for alkalinity, $\mathrm{pH}$ and conductivity, and the highest negative loadings for nitrate nitrogen and reactive silica (Tab. 2). These variables are subject to many in-lake modifications, especially through primary production and calcite precipitation, but all are strongly linked to the characteristics and processes operating in the watersheds (geochemical structure of the drainage basins, weathering, precipitation and human influence). With this specification, this factor can be defined as the watershed factor.

The first axis of the factor scores plot (Fig. 2) separates lakes Maggiore and Garda, which are located at the opposite sides of the lake district, the other lakes falling in between. The epilimnetic average values of conductivity, bicarbonates and $\mathrm{pH}$ increase clearly towards the lakes lying in watersheds with a prevalence of calcareous rocks (Lugano, Iseo and Garda) (Fig. 2; Tab. 1). The concentrations of reactive silica show an inverse trend, with a marked decrease from Lago Maggiore towards lakes Como and Iseo, and lowest values in lakes Garda and Lugano. The high conductivity of Lake Iseo derives from the high concentrations of calcium and bicarbonate, and from sulfate originating in gypsum rocks present in the drainage basin (Bonomi et al. 1979; Mosello 1983). Altogether, the average epilimnetic $\mathrm{pH}$ values $\left(\mathrm{pH}_{\text {avg }}\right)$ are positively correlated $(P<0.01)$ with conductivity $(r=0.74)$ and alkalinity $(r=0.80)$, and negatively correlated with reactive silica $(r=-0.70, P$ $<0.01)$.

On an annual basis, the strongest decrease of Si concentrations in the epilimnetic layers was in late winter (Iseo, Como, Lugano, Maggiore) or spring (Garda), as reported in the DSL papers. The minimum values varied between around 0.05 and $0.25 \mathrm{mg} \mathrm{Si}^{-1}$ in lakes Garda, Iseo, Como and Lugano, and between 0.4 and $0.9 \mathrm{mg} \mathrm{Si}$ $1^{-1}$ in Lago Maggiore (Tab. 1). These data are indicative of a potential limitation of diatoms by silica in all the studied lakes apart from Lago Maggiore. However, there may be a potential Si limitation in the upper trophogenic layers even in Lago Maggiore when there is a high dominance of diatoms, as occurred in the year 2000, when a large development of Cyclotella comensis up to mid summer caused silica to drop to about 0.05 $\mathrm{mg} \mathrm{l}^{-1}$ in the top few metres of the water column.

Nitrogen dominated as nitrate in the surface waters of all the considered lakes. The lowest $\mathrm{NO}_{3}-\mathrm{N}$ concentrations were typical of Lake Garda (193-233 $\mu \mathrm{g} \mathrm{N}^{-1}$ as annual epilimnetic averages); they were three or four

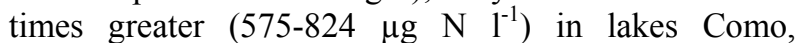
Maggiore and Iseo, while Lake Lugano showed intermediate values (340-430 $\mu \mathrm{g} \mathrm{N}^{-1}$ ). The lower concentrations in Lake Garda are probably related to its high water renewal times (Fig. 1) (Ambrosetti et al. 1992). In this lake the summer epilimnetic nitrate concentrations were far lower than in the other lakes (Tab. 1). The decrease of nitrate was more accentuated at the surface, where it reached summer minimum values below $10 \mu \mathrm{g}$ $\mathrm{N}^{-1}$ after the two complete overturns of 1999 and 2000. In the other lakes, very low surface concentrations (between barely detectable values and $30 \mu \mathrm{g} \mathrm{N}^{-1}$ ) were reached only in Lake Lugano in the same years, i.e. after two episodes of greater vertical mixing and higher phytoplankton production. These data indicate that a marked limitation of phytoplankton growth in the top metres of the water column in lakes Garda and Lugano during the summer months may be determined by nitrogen as well as phosphorous, and that this limitation increases in importance after stronger spring mixing episodes and P replenishment. However, the importance of $\mathrm{N}$ as a limiting factor within the euphotic zone lessens markedly with increasing depth (Salmaso 2000; Simona 2003).

The second factor has the highest positive loadings for chlorophyll- $a$, phytoplankton biovolume, total phosphorus and, partly, conductivity, and the highest nega- 
tive loadings for transparency (Tab. 2). This factor is strongly dependent on the variables expressing the lakes' trophic status, and may be referred to as the trophic factor. The second axis of the ordination diagram (Fig. 2) distinguishes the more eutrophic lakes (Iseo and Lugano, with the exclusion of Lugano in 1998) from the mesotrophic (Como, station of Como) and oligo-mesotrophic (Garda, Maggiore and Como-Abbadia L.) basins.

The highest and lowest annual average transparency values were found in Lake Garda (7.2-10.6 m) and Lake Iseo (4.9-6.2 m), respectively; lakes Como, Lugano and Maggiore were characterised by intermediate values (5.5-8.1 m). Overall, the annual average values of transparency were linked to the annual evolution of phytoplankton biomass, expressed both as annual averages of chlorophyll- $a\left(r^{2}=0.34, P<0.05\right)$ and phytoplankton biovolume $\left(r^{2}=0.35, P<0.05\right)$. However, caution should be taken when using transparency for the trophic determination of these large water bodies. Salmaso et al. (2001b) found some inconsistencies in the assessment of the trophic status of Lake Garda made using Secchi disk depths compared with other trophic estimators (cf. also Tab. 1). Morabito et al. (2002) showed that in Lago Maggiore a significant amount of light attenuation was due to non-phytoplankton material. The greater inflow and the reduced renewal time of Lago Maggiore compared with Lake Garda may result in a larger amount of inorganic suspended material in the water column and, under comparable trophic conditions, lower transparencies.

Overall, chlorophyll- $a$ (both $\mathrm{Chl}_{\mathrm{avg}}$ and $\mathrm{Chl}_{\max }$ ) was strongly related to the availability of $\mathrm{TP}\left(\mathrm{TP}_{\text {lake }}, \mathrm{TP}_{\mathrm{MaxSp}}\right.$ and $\left.\mathrm{TP}_{\text {avg }} ; 0.41<r^{2}<0.65, P \leq 0.01\right)$. However, owing to the high variability observed in lakes Iseo and Lugano, these relationships did not hold for the biovolume values, indicating a different and variable response of the phytoplankton community in these two waterbodies to high P replenishment events (Garibaldi et al. 2003; Simona 2003).

The stations which were more impacted by mixing overturn and phosphorus replenishment in 1999 and 2000 (Iseo, Lugano and Garda; section 4.1) score high along the second axis of the ordination diagram in comparison to the 1998 cases. In particular, the impact determined a clear separation of the 1998 and 1999-2000 cases in lakes Lugano and Iseo, with a more gradual differentiation in Lake Garda (Fig. 2, Table 1).

\subsection{Dominant phytoplankton taxa}

There were 46 taxa exceeding biovolume peaks of $100 \mathrm{~mm}^{3} \mathrm{~m}^{-3}$ in the considered lakes and study periods. In the following analyses, taxa found in less than 4 study periods and/or lake stations will not be considered. This subgroup includes the taxa present during a single study year (Chlorella vulgaris and Asterococcus superbus in Lake Iseo, and undetermined filaments ascribed to the Ulothrichales in Lake Garda) or in single lakes (undetermined Chroococcales in Lake Lugano); the other taxa excluded from the analysis are Trachelomonas sp. and Navicula sp., and a group of small cryptophytes difficult to identify (Chroomonas sp. ?).

The final 39 taxa are reported in table 3 . These were represented mainly by Cyanobacteria ( 8 taxa), Chlorophyceae (8 taxa), Bacillariophyceae (9 taxa) and Chryso- and Haptophyceae (5 taxa). The Conjugatophyceae, Xantophyceae, Dinophyceae and Cryptophyceae were each represented by 1-3 taxa. For lakes Garda, Iseo, Lugano and Maggiore, table 2 reports the average values of the maximum annual biovolume values recorded in the three study years; for Lake Como, the peaks of biovolume refer to the whole study period (September 1997-August 1999).

With a few exceptions, the species reported in table 3 were historically recorded in all the considered lakes (see, for example, Ruggiu 1983). The absence of one species in a lake indicates its recent low importance in the phytoplankton community. Among the cyanobacteria, some consolidated major differences are the strong development of Aphanizomenon flos-aquae in Lake Lugano and its presence in Lago Maggiore, and the occurrence of oligotrophic blooms of Anabaena lemmermannii in lakes Garda and Iseo (Salmaso 2000). In any case, considering the major changes observed in the phytoplankton community since the 1950s in response to the changes in the trophic level of the DSL (e.g., Mosello \& Ruggiu 1985; Ruggiu 1989; Ruggiu et al. 1998; Salmaso 2002; section 4.6), Table 3 allows a comparison of the lakes in their present trophic condition.

Figures 3 to 6 report the seasonal changes of some selected species listed in table 3 . To increase readability, only the most eutrophicated station in Lake Como was considered ("Como"); the most important differences between this and the station of Abbadia-L. will be discussed in the text (see also Buzzi 2002). The species not included in the graphs will be briefly examined, also taking account of the information reported in the DSL papers.

Of the cyanobacteria (Fig. 3, Tab. 3) the most representative taxon was Planktothrix rubescens/ag., with highest biovolumes found in lakes Iseo and Como. Filaments of Planktothrix were present during most of the year, with highest biovolumes in summer and autumn. During the warmest months, this taxon may develop in deep lakes with localised populations in the metalimnetic layer, close to the lower limit of the euphotic zone (Micheletti et al. 1998; Salmaso 2002). The remaining Oscillatoriales were represented by Oscillatoria limnetica, Limnotrichoideae and Planktolyngbya limnetica, the first two of these taxa showing occasional (O. limnetica) or irregular (Limnotrichoideae) developments. The population of Limnotrichoideae (Limnothrix sp. (?)) in Lake Garda is mainly limited to the summer months (June-September), but with irregular biomass 


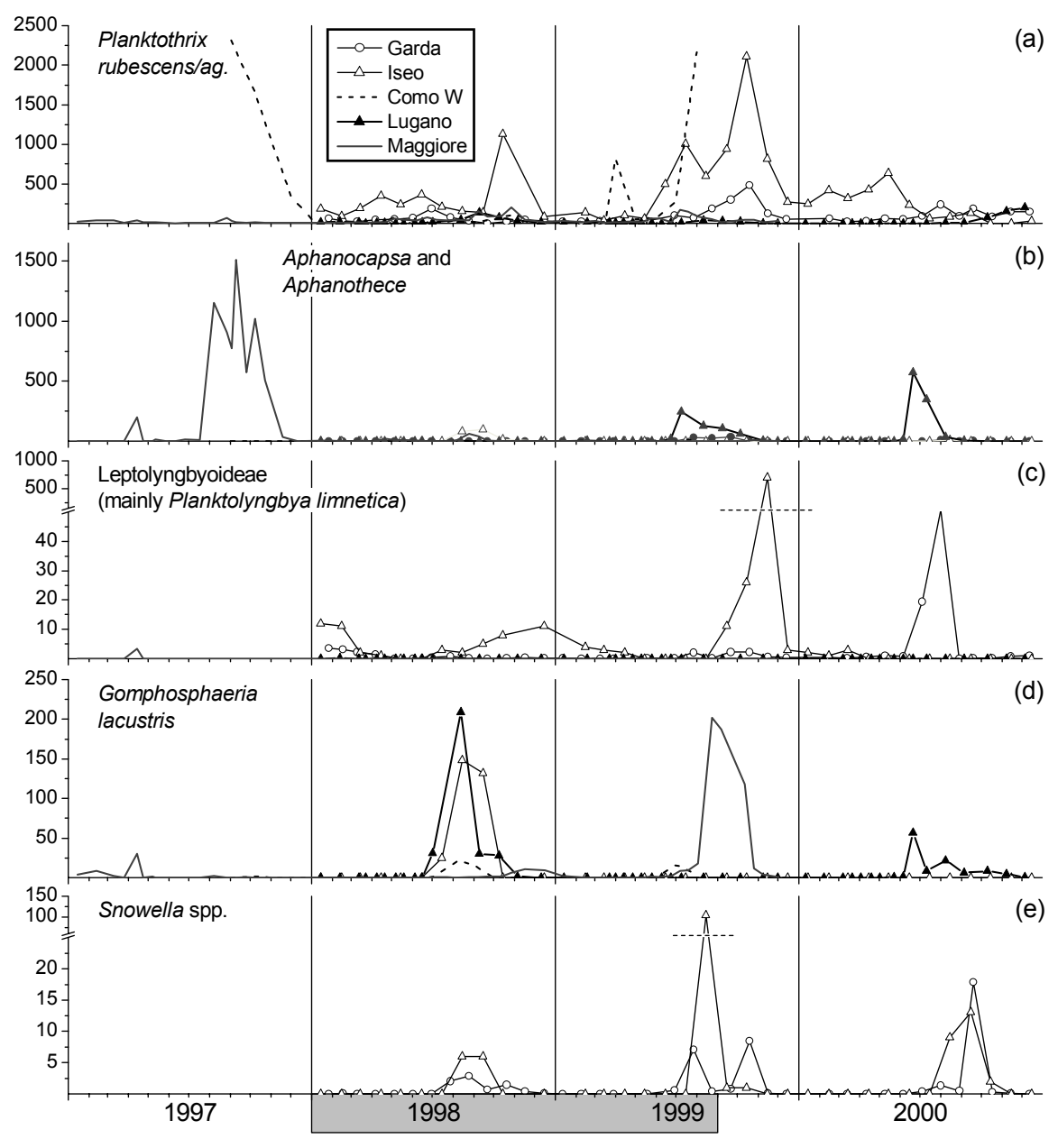

Fig. 3. Temporal variation of biovolumes $\left(\mathrm{mm}^{3} \mathrm{~m}^{-3}\right)$ for the most abundant cyanobacteria in the lakes Maggiore (1997-1999), Como (station of Como; September 1997-August 1999), and Garda, Iseo and Lugano (1998-2000). As in the following figures 4-6, the shaded area indicates the period when the information was simultaneously available for all five lakes.

growth in the different years and occasional occurrences in other periods (spring or late autumn) (Salmaso 2003). $P$. limnetica occurred almost exclusively in the E lakes Iseo and Garda, mainly during the summer and autumn months (Fig. 3c).

Of the Chroococcales, the colonies belonging to the genera Aphanocapsa and Aphanothece characterised the summer and autumn phytoplankton assemblages of all five lakes, but with different seasonal peaks (Fig. 3b). The largest development of these colonies occurred in lakes Como (Abbadia-L.), Lugano and Maggiore, with the maximum peaks recorded in 1997 in Lago Maggiore (Aphanothece clathrata). Gomphosphaeria (Snowella) lacustris was mainly present in summer and early autumn, and colonies belonging to Snowella spp. were limited to the E lakes Iseo and Garda. (Figures 3d-e).

Aphanizomenon flos-aquae is the only Nostocales reported in table 3 . This species was found exclusively in the $\mathrm{W}$ lakes, with a regular (Lugano) or irregular (Maggiore) appearance and with different biovolume peaks in the different years (Morabito et al. 2002; Simona 2003). A Nostocales not included in table 3, but which is a characteristic component of the phytoplankton communities in the E lakes Garda and Iseo, is Anabaena lemmermannii. During the 1990s this cyanobacterium developed occasional summer oligotrophic blooms, i.e. blooms strictly localised in the top few centimetres of the water column and with low overall biovolumes in the trophogenic layers (Salmaso 2000). Heterocystous cyanobacteria present an interesting problem in these lakes. The blooms of A. lemmermannii, which were restricted to lakes Garda (oligo-mesotrophic) and Iseo (meso-eutrophic), do not appear to be linked to a precise trophic gradient. Moreover, no apparent relationship exists between summer $\mathrm{N}$ depletion and the development of Nostocales in the DSL. The summer in- 
Tab. 3. Dominant phytoplankton taxa (with annual biovolume peaks $>100 \mathrm{~mm}^{3} \mathrm{~m}^{-3}$ ) identified in the specified periods in the DSL. For each species, the table reports the identification code and the average values of the annual peaks of biovolume recorded over a three study period (Garda, Iseo, Lugano and Maggiore), or the single biovolume peaks recorded from September 1997 to August 1999 (Como). ${ }^{(1)}$ Mainly Planktolyngbya limnetica; ${ }^{(2)}$ including R. minuta v. nannoplanctica.

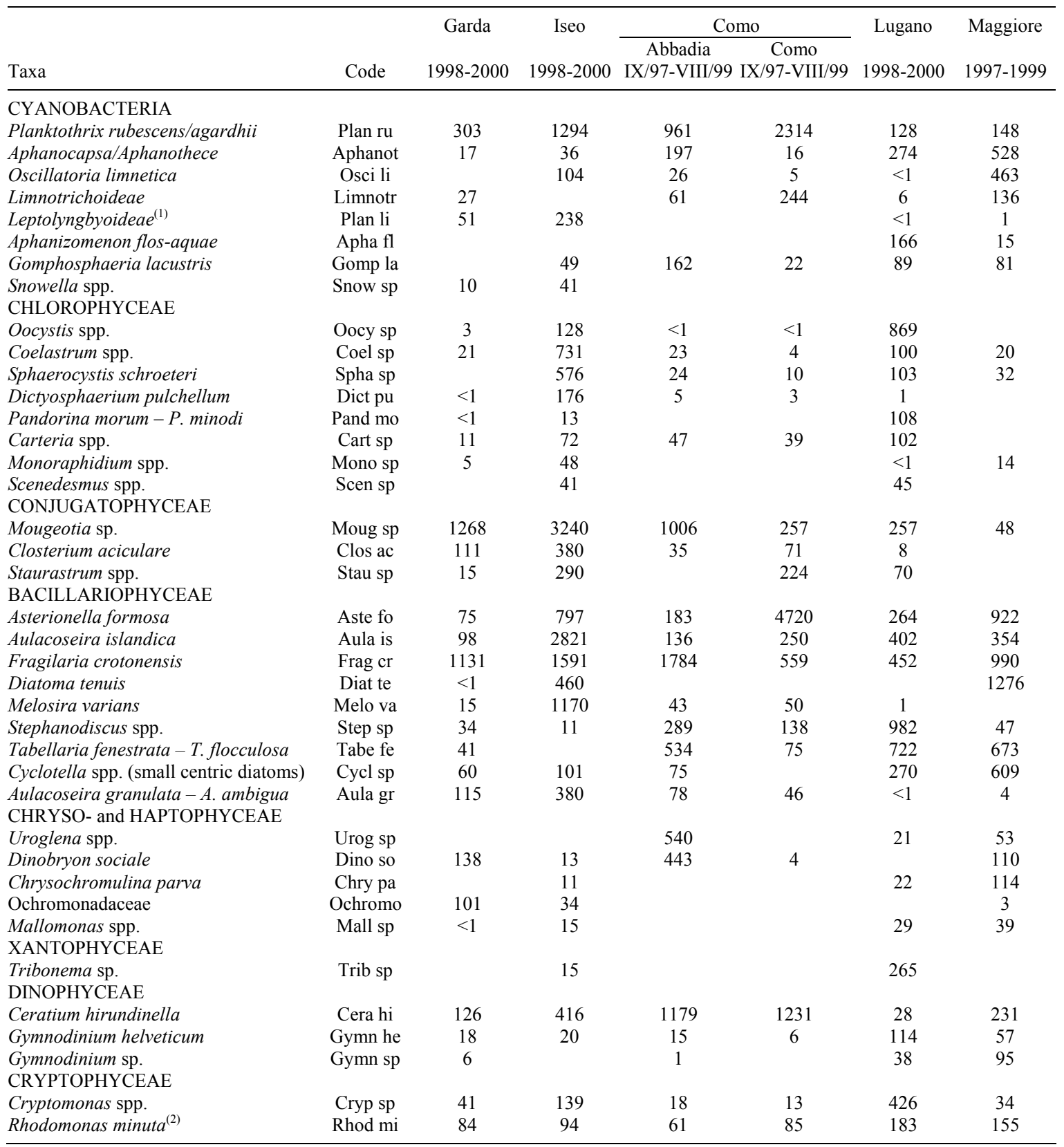

crease of Anabaena in Lake Garda and Aphanizomenon in Lake Lugano during high $\mathrm{N}$ depletion may confirm this. However, significant developments of Aphanizomenon were observed even before nitrate exhaustion (LSA 1995; Simona 2003); moreover, in Lake Iseo the epilimnetic nitrate concentrations are high even during the summer months (section 4.2), which suggests that the distribution of Nostocales in the DSL is determined by other factors besides the ability to fix atmospheric N.
The Chlorophyceae were largely represented by numerous Chlorococcales (Tab. 3). The species belonging to this order respond positively to the increasing thermal stability in temperate lakes (cf. Reynolds 1996, 1997), growing with a high temporal synchronicity and sharing common adaptations to contrast sinking and/or grazing (e.g., Salmaso 2003). Collectively, these species dominated the phytoplankton community from late spring or early summer to early autumn in the more eutrophic lakes Iseo and Lugano (Fig. 4a). The Volvocales (Pan- 


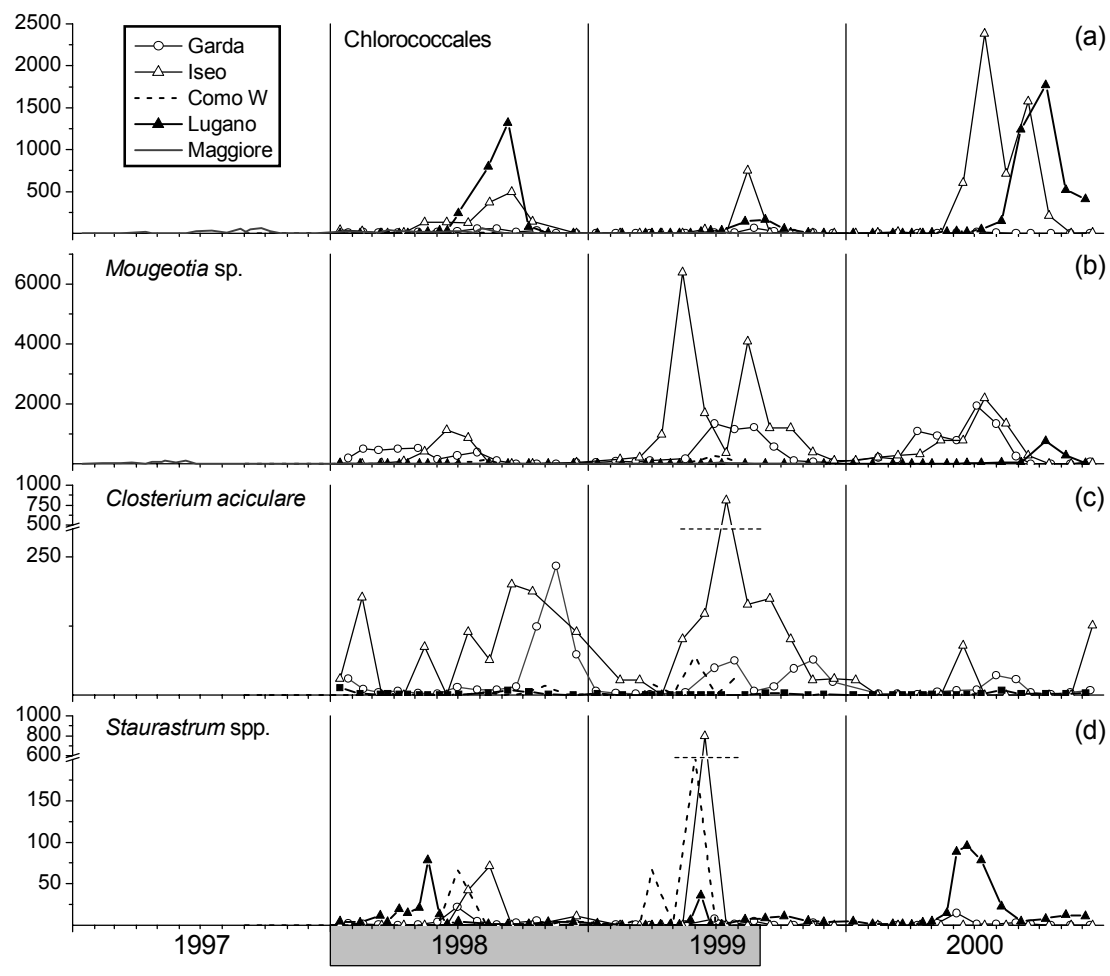

Fig. 4. Temporal variations of biovolumes $\left(\mathrm{mm}^{3} \mathrm{~m}^{-3}\right)$ for the most abundant chlorophytes in the lakes Maggiore (1997-1999), Como (station of Como; September 1997-August 1999), and Garda, Iseo and Lugano (1998-2000).

dorina spp. and Carteria spp.) showed irregular seasonal development and (in the case of Pandorina) irregular geographic distribution.

The Conjugatophyceae were characterised by a very strong development of Mougeotia in lakes Iseo and Garda (Fig. 4a). Excluding a single biovolume peak recorded in the E branch of Lake Como (Abbadia-L; Buzzi 2002), this taxon showed a progressive reduction towards the lakes located farther W (Lugano and Maggiore). Its development during the spring and summer months is favoured by its success as a competitor for phosphorus and its good resistance to sinking and grazing (Sommer 1987; Padisák et al. 2003). In Lake Garda this taxon collapses during the summer months (Salmaso 2000, 2002). In contrast, Mougeotia occasionally persists with large populations in late summer in Lake Iseo (Garibaldi et al. 2003), so it may be favoured by the higher availability of nutrients (both $\mathrm{P}$ and $\mathrm{N}$ ) in this meso-eutrophic lake (sections 4.1 and 4.2). Two other important conjugatophytes in the DSL are Closterium aciculare and Staurastrum spp. Like Mougeotia sp., C. aciculare developed with higher biovolumes in the E lakes (Fig. 4c). Staurastrum spp. developed in a fairly delimited period, i.e. from late spring to mid summer (Fig. 4d).

Apart from Diatoma tenuis, which was really abundant only in Lago Maggiore, the pennate diatoms were widely represented in the DSL (Tab 3). Asterionella formosa had its maximum development in early spring (Fig. 5a), whereas Tabellaria was characterised by a longer temporal evolution, from late autumn to early spring (Fig. 5e). It is more difficult to generalise about the seasonal evolution of $F$. crotonensis, due to its continuous presence in the phytoplankton community (Fig. 5c).

The centric diatoms were less uniformly distributed both in space and seasonally, though they were present among the dominants in all five lakes. Only Aulacoseira islandica was a typical species in all the considered lakes. Melosira varians and Aulacoseira granulata/ambigua were mainly present in the lakes Garda, Iseo and Como, whereas Stephanodiscus sp. and, partly, the small centric diatoms (Cyclotella spp.), showed a tendency to a more intense growth in lakes Lugano, Como and Maggiore (Tab. 3). The filamentous centric diatoms stood out for their marked temporal delimitation in the early spring period (Figs $5 \mathrm{~b}, 5 \mathrm{~g}$ ). With few exceptions, this characteristic was also shared by Stephanodiscus spp. (Fig. 5d). In contrast, the small centric diatoms showed a longer temporal distribution (Fig. 5f); however, the development of this group during spring was observed only in the $\mathrm{W}$ lakes. 


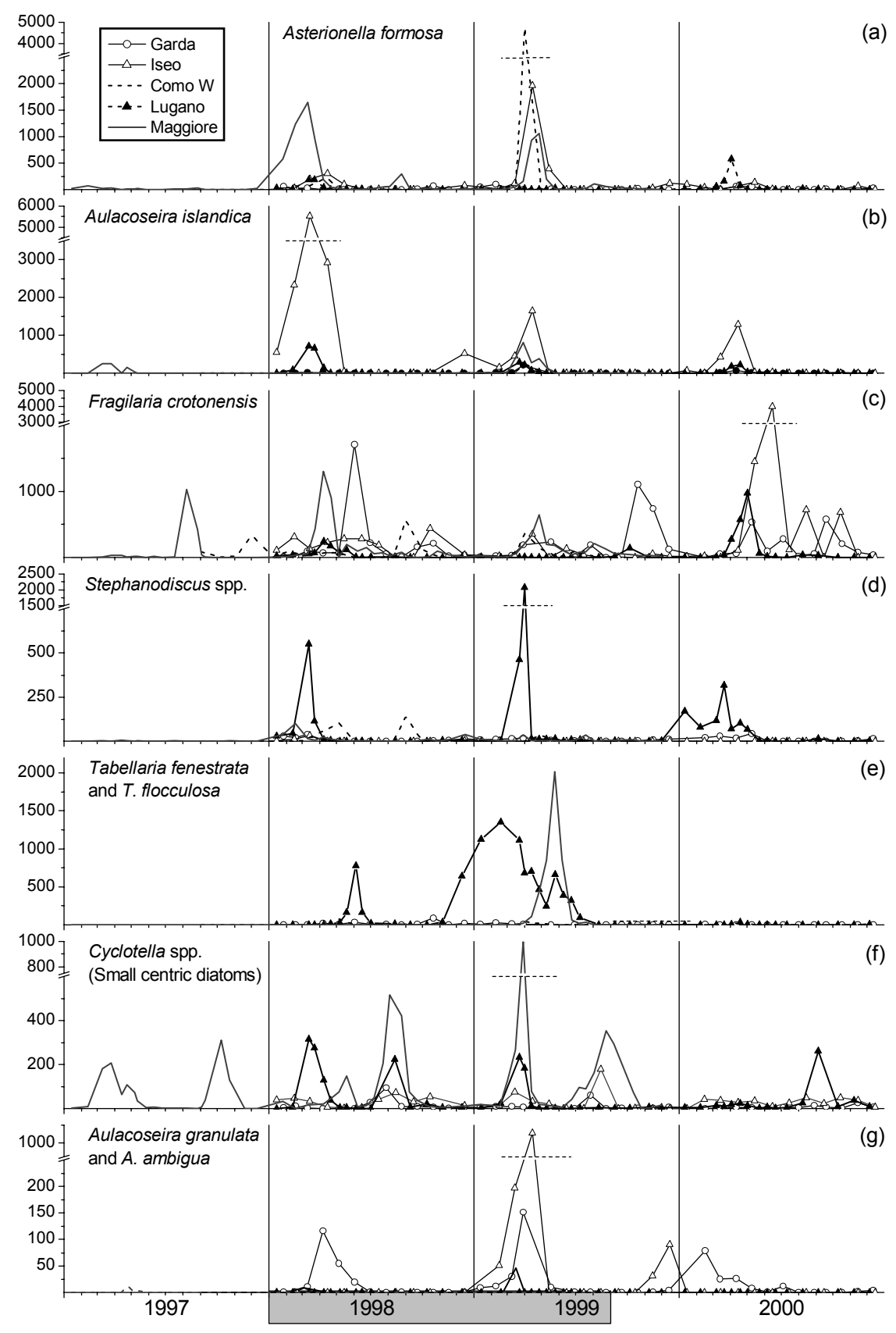

Fig. 5. Temporal variations of biovolumes $\left(\mathrm{mm}^{3} \mathrm{~m}^{-3}\right)$ for the most abundant diatoms in the lakes Maggiore (1997-1999), Como (station of Como; September 1997-August 1999), and Garda, Iseo and Lugano (1998-2000).

The diatoms declined with the onset of thermal stability in the water column and with reduced availability of silica. Salmaso (2003) found in Lake Garda an almost equivalent low tolerance against thermal stability and $\mathrm{Si}$ depletion in Stephanodiscus sp., A. islandica, A. granulata and $A$. formosa, an increasing tolerance in $F$. crotonensis, and a maximum tolerance in the small Cyclotella spp. However, the decline of the large centric diatoms and Asterionella began before Si was at its lowest, suggesting that a major role is played by increasing thermal stability in this respect (Salmaso 2002; 2003; Garibaldi et al. 2003). Overall, these data indicate that, among the largest diatoms, only the flat, ribbon-like colonies of Fragilaria may be able to compensate their sinking losses and achieve a net positive growth in stratified and moderately nutrient-depleted water columns. Padisák et 


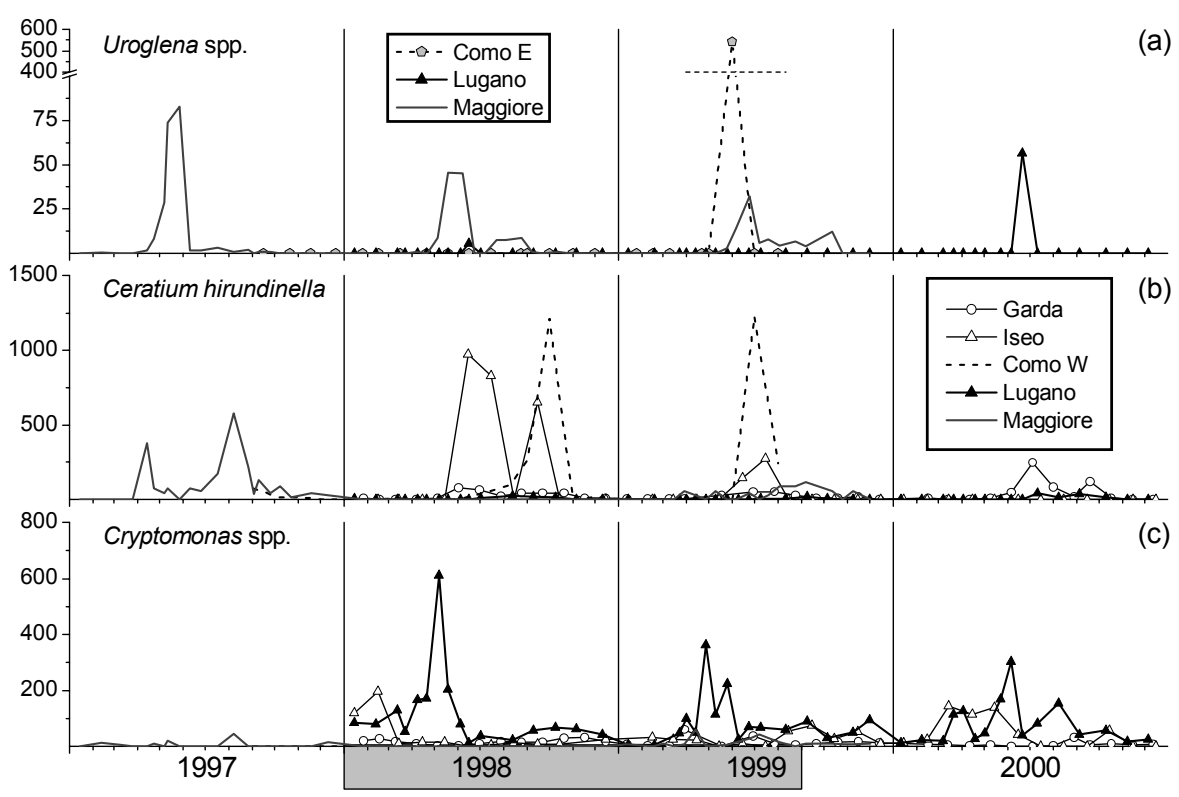

Fig. 6. Temporal variations of biovolumes $\left(\mathrm{mm}^{3} \mathrm{~m}^{-3}\right)$ of some selected species in the lakes Maggiore (1997-1999), Como (stations of Abbadia L. (a) and Como (b, c); September 1997-August 1999), and Garda, Iseo and Lugano (1998-2000).

al. (2003) found that colonies of Fragilaria of more than 8 cells rapidly increased their resistance against sinking (estimated by the "form resistance" $\Phi$ ) with increasing cell numbers, reaching the highest $\Phi$ value that was recorded in any of their experiments.

Among the Chrysophyceae, an occasional constituent of Lake Como and of the $\mathrm{W}$ lakes Lugano and Maggiore was Uroglena spp. (Tab. 3; Fig. 6a). Dinobryon sociale developed from late spring to mid summer in all of the lakes except Lake Lugano, where however it grew with significant biovolumes in the following years (up to $646 \mathrm{~mm}^{3} \mathrm{~m}^{-3}$ in 2002; M. Simona, unpublished data). In the study periods considered here, a further species of Dinobryon (D. divergens) was recorded with lower biovolume peaks $\left(<60 \mathrm{~mm}^{3} \mathrm{~m}^{-3}\right)$ in all the DSL except Lake Como. The Ochromonadaceae (mainly represented in the E lakes Garda and Iseo) increased from late spring to mid summer, whereas Chrysochromulina parva showed a longer and more irregular temporal development.

Two other typical constituents of the DSL are Ceratium hirundinella and Cryptomonas spp. (Tab. 3, Figs 6b-c), which had their greatest development in lakes Como and Lugano, respectively. On the whole, $C$. hirundinella was abundant from spring to mid summer and/or early autumn, whereas Cryptomonas spp. showed a longer and more irregular temporal evolution. The remaining species reported in table 3 displayed a less regular seasonal development, with a major localisation in the W lakes Lugano and/or Maggiore (Mallomonas spp., Tribonema sp. and Gymnodinium sp.) or a more homogeneous geographic distribution (Rhodomonas minuta and Gymnodinium helveticum) (cf. the DSL papers, section 3).

\subsection{Synthetic representations of the seasonal and geographic distribution of the phytoplankton taxa}

A synthetic representation of the geographic and seasonal distribution of the dominant phytoplankton taxa described in the previous section is given in table 4 . The table has been structured to consider five seasonal periods defined on the basis of the temporal evolution of the taxa reported in figures 3-6, with the addition of $M$. varians, Ochromonadaceae, C. parva, D. sociale, Aphanizomenon flos-aquae and A. lemmermannii; cf. section 4.3). The choice of periods is consistent with the models of temporal phytoplankton evolution described for lakes Garda (Salmaso 2000; 2002) and Maggiore (Morabito et al. 2002), and reflects the greater turnover rates of the community from the spring to the autumn months, when autogenic processes of community reorganisation prevail, and the relative homogeneity during the coldest months, when allogenic factors prevail (Salmaso 2003).

Table 4 takes into account two important features of the phytoplankton in the DSL, namely the high interannual variability and the high asymmetry in geographic distribution that marks out some species; these two aspects will be discussed below and in the next section. As regards the first feature, the arrangement of the dif- 
Tab. 4. Synthetic representation of the seasonal distribution of the most representative phytoplankton taxa in the DSL. The species names are abbreviated as in table 3. The species developing with greater abundances or exclusively present in the E (Garda and Iseo) or W (Maggiore, Lugano) lakes have been highligthed in bold. ${ }^{(1)}$ Spring peak observed in lakes Maggiore and Lugano; ${ }^{(2)}$ Species not recorded in Lago Maggiore; ${ }^{(3)}$ Species not recorded in Lake Garda; ${ }^{(4)}$ Species not recorded in Lake Como; ${ }^{(5)}$ Species not recorded in Lake Lugano; ${ }^{(6)}$ "Oligotrophic" surface blooms in the lakes Garda and Iseo, with biovolume peaks in the epilimnetic layers $<100 \mathrm{~mm}^{3} \mathrm{~m}^{-3}$ (Salmaso 2000). For further details see the section 4.4 .

\begin{tabular}{|c|c|c|c|c|c|}
\hline & $\begin{array}{l}\text { Late winter- } \\
\text { Mid Spring }\end{array}$ & Late Spring & $\begin{array}{l}\text { Early and } \\
\text { mid summer }\end{array}$ & $\begin{array}{l}\text { Late Summer- } \\
\text { Mid Autumn }\end{array}$ & $\begin{array}{l}\text { Late Autumn- } \\
\text { Mid Winter }\end{array}$ \\
\hline & Aste fo & & & & \\
\hline & Aula is & & & & \\
\hline & Step sp & & & & \\
\hline $\mathrm{E}(+\mathrm{Como})$ & Aula gr & & & & \\
\hline E (+Como) & Melo va & & & & \\
\hline \multirow[t]{4}{*}{$\mathrm{W}$ (+Como) } & Tabe fe * & * & & & $*$ \\
\hline & Cryp sp & Cryp sp & Cryp sp & Cryp sp & $*$ \\
\hline & Frag cr & Frag cr & & Frag cr & $(*)$ \\
\hline & Cycl sp ${ }^{(1)}$ & $*^{(1)}$ & Cycl sp & & \\
\hline \multirow[t]{2}{*}{ E (+Como) } & Moug sp & Moug sp & Moug sp & $*$ & $*$ \\
\hline & $*$ & Cera hi & Cera hi & $*$ & \\
\hline \multirow{3}{*}{$\begin{array}{c}\mathrm{E}(+ \text { Como }) \\
\mathrm{E} \\
(2)\end{array}$} & $*$ & Clos ac & Clos ac & Clos ac & $*$ \\
\hline & & Ochromo & $*$ & & \\
\hline & & Stau sp & Stau sp & & \\
\hline \multirow{3}{*}{$\mathrm{W}(\underset{\text { (3) (4) }}{+ \text { Como })}$} & & Urog sp & Urog sp & & \\
\hline & & Chry pa & Chry pa & $*$ & \\
\hline & $*$ & * & Plan ru & Plan ru & $*$ \\
\hline \multirow[t]{2}{*}{ (5) } & & $*$ & Dino so & & \\
\hline & & $*$ & Chloroc & $*$ & \\
\hline (3) & & $*$ & Gomp la & $*$ & \\
\hline $\mathrm{E}$ & & $*$ & Anab le $e^{(6)}$ & $*$ & \\
\hline \multirow[t]{2}{*}{ W } & & $*$ & Apha fl & $*$ & $*$ \\
\hline & & & Aphanot & Aphanot & \\
\hline $\mathrm{E}$ & & & Snow sp & Snow sp & \\
\hline $\mathrm{E}$ & $*$ & & * & Plan li & $*$ \\
\hline
\end{tabular}

ferent taxa in the table aims to identify their most probable (potential) temporal location, leaving out of consideration the differences in absolute abundance with the other taxa, or of the same taxon in different lakes. A characteristic or more regular presence of one taxon in one of the five seasonal periods is indicated by the code written in full, whereas occasional and irregular development is marked by an asterisk. The relative importance of the different species in a single lake may be evaluated by consulting table 3 . As for the geographic distribution, the major differences were found between the E lakes (Garda and Iseo) and those in the W (Maggiore and Lugano), with intermediate conditions in Lake Como. In table 4 these differences are highlighted in bold, and include the dominant or exclusive presence of A. granulata/ambigua, M. varians, Mougeotia sp., C. aciculare, Ochromonadaceae, A. lemmermannii, Snowella spp. and P. limnetica in lakes Garda and Iseo, and Tabellaria spp., Uroglena sp. and Aphanizomenon flos-aquae in lakes Maggiore and Lugano. Despite these differences, common patterns are identifiable in the sequence of the seasonal assemblages, which were mainly represented by large diatoms in late winter and mid spring, and by chrysophytes, conjugatophytes and dinophytes in late spring; these groups were also represented in the summer assemblages, which showed, however, a higher diversity, with an increasing importance of cyanobacteria (Chroococcales, Nostocales and Oscillatoriales), chlorophytes (many Chlorococcales) and small centric diatoms. The diversity decreased in late summer and mid autumn, with the persistence of many cyanobacteria and of the species present throughout the year ( $F$. crotonensis, Cryptomonas spp., P. rubescens/ag. and, primarily in the E lakes, Mougeotia sp. and C. aciculare).

The DSL papers contain comments on the factors driving the seasonal successions of the phytoplankton communities in large, deep lakes. Considerations on the phytoplankton assemblages of the DSL in the light of algal life-style strategies proposed by Reynolds (1997) and Reynolds et al. (2002) are reported in Salmaso (2000, 2002) and Morabito et al. (2002, 2003).

The seasonal and interannual variations of some selected species in the various lakes presented different levels of regularity and predictability (see Figs 3-6 and the DSL papers). Lake Garda is characterised by the high stability of its algal communities, and has been described as being one of the best examples of year to year similarity in distribution and composition of lake phytoplankton in deep lakes (e.g., Salmaso 2003). In this lake, during the major fertilisation events of the biennium 1999-2000, the phytoplankton biovolume increased, but without changing its basic structure. In contrast, a high degree of interannual variability exists in Lake Lugano, with different species becoming dominant in response to the major fertilisation events in 1999 and 2000 (Simona 

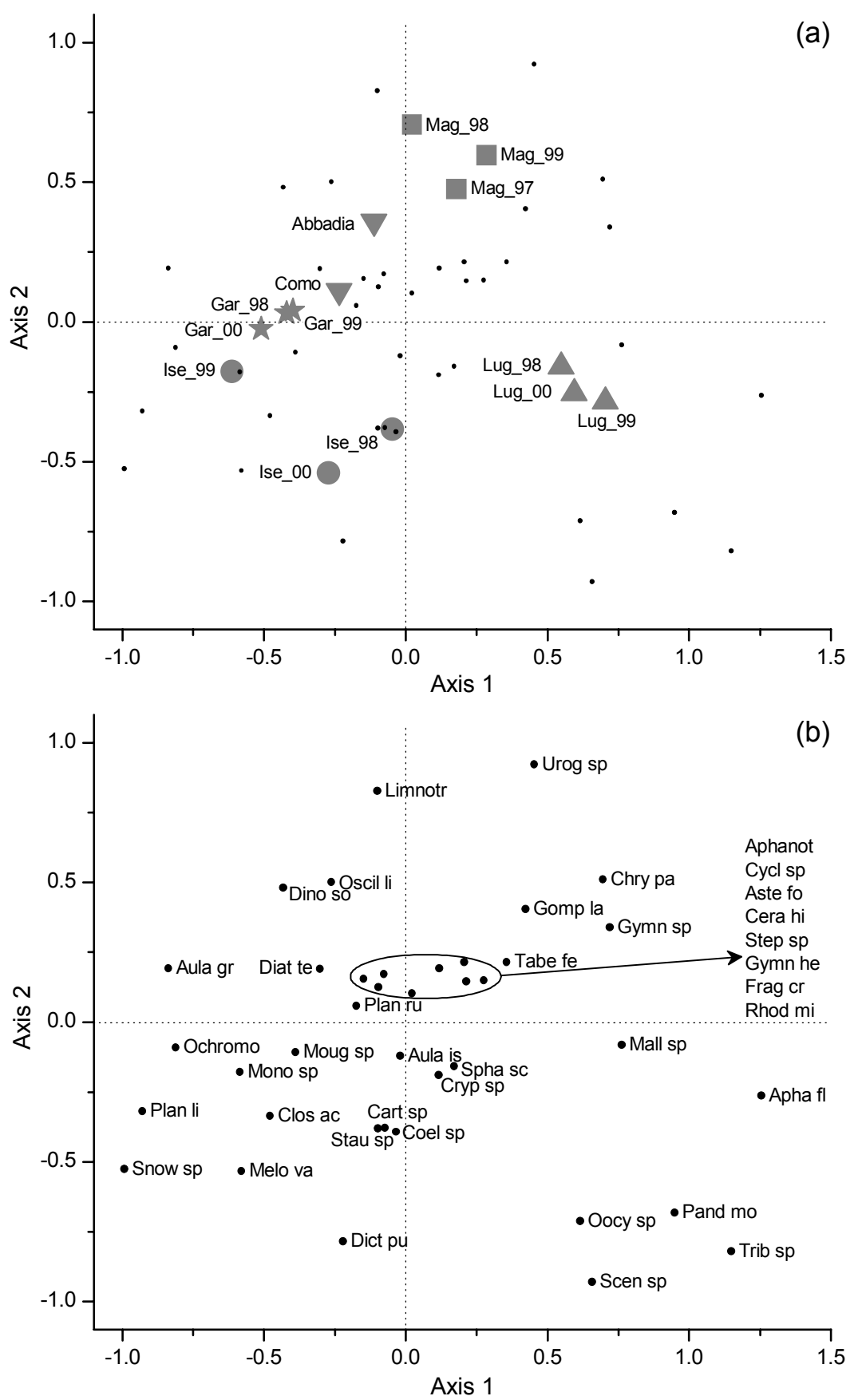

Fig. 7. Ordination of (a) the DSL and (b) phytoplankton taxa in the correspondence analysis plane defined by the first two axes. The single cases in (a) have been coded as in figure 2; species names in (b) are abbreviated as in table 3.

2003); similar conditions also prevailed in Lake Iseo (Garibaldi et al. 2003). Lago Maggiore seems to be in an intermediate position, while more extensive studies would be required to assess the situation in Lake Como. A possible reason for the greater stability of the phytoplankton community in Lake Garda may be its greater volume, associated with a lower water inflow and higher renewal time (Fig. 1), which confers high inertia and resilience to perturbations (e.g. meteorological events). In the remaining lakes, the higher water inflows and shorter water renewal time, along with a more ar- ticulated hydrography and, particularly in the case of lakes Iseo and Lugano, lower water volumes, may significantly lessen their inertial properties. This idea is supported by the studies conducted on Lago Maggiore by Morabito (2001), who found a significant impact of the meteorological and hydrological conditions acting on the phytoplankton community over a short timescale.

The interpretation of table 4 is complicated because some species attain high abundances in lakes with opposite trophic levels, whereas other abundant taxa (e.g. the numerous Chlorococcales) are principally distributed in 
the meso- and eutrophic lakes (Tab. 3). These aspects will be examined in the next section.

\subsection{Correspondence analysis}

The simultaneous ordination of the 5 lakes and phytoplankton on the basis of the biovolume peaks recorded in the study periods is illustrated in figure 7; the eigenvalues associated to the first two CA axes are 0.18 and 0.13 , respectively.

The left and right quadrants of figure 7 a separate the E lakes (Garda and Iseo) and those in the W (Lugano and, to a lesser extent, Maggiore); along this axis, the two stations of Lake Como seem to have different characteristics, intermediate between the two geographic districts (Abbadia-L.), or closer to the E lakes (station of Como). The second axis separates the more eutrophic lakes (Iseo and Lugano) from the mesotrophic (Como, station of Como) and oligo-mesotrophic ones (Maggiore, Garda and Como, station of Abbadia-L.). The simultaneous ordination of the phytoplankton, based on the maximum annual peaks (Fig. 7b), essentially confirms the results reported in the previous two sections. Species are located closer to the samples they occur in. In particular, among the species contributing to the differentiation of the $\mathrm{E}$ and $\mathrm{W}$ geographical districts, the location in the left quadrants of $M$. varians, $A$. granulata/ambigua, P. limnetica, Snowella spp., Ochromonadaceae, Mougeotia sp. and C. aciculare is clear. The right quadrants are typified by the presence of Uroglena sp., Mallomonas spp., C. parva, Gymnodinium sp., Tribonema sp. and Aphanizomenon flos-aquae. A further typical trait is that the Chlorococcales and Volvocales are located strictly in the lower quadrants.

The robustness of the ordination obtained by CA was confirmed by NMDS analyses, which ordinated the lakes and the phytoplankton taxa separately on planes defined by couples of orthogonal axes fully interpretable as in Figures 7a and 7b. After Procrustes rotation, in the case of the lakes, axes 1 and 2 obtained by NMDS were strongly $(P<<0.01)$ correlated with the corresponding first two CA axes (with Pearson correlation coefficients, $r$, equal to 0.96 and 0.95 , and Spearman rank order correlations, $r_{s}$, equal to 0.97 and 0.95 , respectively). Similarly, in the case of the ordination of the species, the first two NMDS axes showed a high $(\mathrm{P}<<0.01)$ correlation with the corresponding first two CA axes $\left(r=0.95\right.$ and 0.89 , and $r_{s}=0.97$ and 0.87 , respectively).

The dependence of the rank along the second axis of the lakes and phytoplankton on the trophic level is confirmed by the strict correlations existing between the lakes' coordinates (in Fig. 7a) and the environmental descriptors (Tab. 1) of the trophogenic layers (Tab. 5). The second axis is strictly and negatively correlated with the annual maximum and average concentrations of chlorophyll- $a$, and with the annual averages of phytoplankton biovolume; similarly, the average epilimnetic values of TP showed a negative - although lower relationship with the second axis. However, both the second and the first axis were strictly correlated $(r=$ 0.61 and 0.68 , respectively; $0.01<P<0.05$ ) with the lakes' potential trophic status (expressed as $\mathrm{TP}_{\text {lake}}$ ). Moreover, the second axis was positively correlated with the annual averages and minimum values of reactive silica, negatively correlated with the annual averages and minimum values of alkalinity and conductivity and with the annual averages of $\mathrm{pH}$. The strict dependence of the second CA-axis on groups of variables associated to trophic state and watershed characteristics (section 4.2) is confirmed by its high correlation with the first (the trophic factor) and the second (the watershed factor) axes of figure 2 (Tab. 5).

Tab. 5. Correlations between the first two CA-Axes and the environmental variables (for legend see table 1) and the first two axis of the factor analysis (cf. Fig. 2). (a): Pearson correlation coefficients $(r)$; $(\mathbf{b})$ : Spearman rank order correlations $\left(r_{s}\right)$; figures in bold and italics are significant at $P<0.01$ and $P<0.05$, respectively. ${ }^{(1)} P<0.10$.

\begin{tabular}{|c|c|c|c|c|}
\hline & \multicolumn{2}{|c|}{ CA-Axis (a) } & \multicolumn{2}{|c|}{ CA-Axis (b) } \\
\hline & I & II & I & II \\
\hline $\mathrm{TP}_{\mathrm{avg}}$ & 0.30 & $-0.47^{(1)}$ & 0.13 & -0.54 \\
\hline $\mathrm{Chl}_{\text {avg }}$ & 0.39 & -0.80 & 0.22 & -0.84 \\
\hline $\mathrm{Chl}_{\max }$ & 0.31 & -0.75 & 0.23 & -0.81 \\
\hline$Z_{S_{\text {avg }}}$ & -0.21 & 0.31 & -0.05 & $0.52^{(1)}$ \\
\hline $\mathrm{Z}_{\mathrm{S}_{-} \min }^{-}$ & -0.31 & -0.09 & -0.38 & -0.08 \\
\hline $\mathrm{NO}_{3}-\mathrm{N}_{\text {avg }}$ & 0.07 & 0.41 & 0.21 & 0.42 \\
\hline $\mathrm{NO}_{3}-\mathrm{N}_{\min }$ & 0.09 & 0.40 & 0.24 & 0.35 \\
\hline $\mathrm{Si}_{\mathrm{avg}}$ & -0.05 & 0.63 & 0.02 & $0.49^{(1)}$ \\
\hline $\mathrm{Si}_{\min }$ & 0.09 & 0.72 & -0.12 & 0.66 \\
\hline $\mathrm{Alk}_{\mathrm{avg}}$ & -0.08 & -0.79 & -0.24 & -0.54 \\
\hline $\mathrm{Alk}_{\min }$ & -0.09 & -0.65 & -0.29 & $-0.52^{(1)}$ \\
\hline Cond $_{\text {avg }}$ & -0.29 & -0.93 & -0.38 & -0.86 \\
\hline Cond $_{\min }$ & -0.36 & -0.86 & -0.55 & -0.71 \\
\hline $\mathrm{pH}_{\mathrm{avg}}$ & -0.36 & -0.69 & -0.48 & -0.63 \\
\hline $\mathrm{pH}_{\max }$ & -0.44 & -0.13 & -0.38 & -0.03 \\
\hline Biov $_{\text {avg }}$ & -0.33 & -0.61 & -0.09 & -0.75 \\
\hline Factor I & -0.16 & -0.67 & -0.25 & $-0.52^{(1)}$ \\
\hline Factor II & 0.11 & -0.70 & 0.12 & -0.74 \\
\hline
\end{tabular}

The dependence of the second CA-axis on these environmental variates is exclusive and is confirmed by the non-significant relationships of the first CA-axis with all the considered variables (with the exclusion of an $r_{s}$ value between Cond $_{\min }$ and CA-axis $1, P<0.05$; Tab. 5). Moreover, the computations of these relationships for the third and fourth CA-axes showed no significant correlations, with the exclusion of a significant association of $\mathrm{Z}_{\mathrm{S} \_ \text {avg }}$ and $\mathrm{Bio}_{\text {avg }}$ with the third axis $(P$ $<0.05)$ and $\mathrm{NO}_{3}-\mathrm{N}_{\min }$ with the fourth axis $(P<0.05)$.

The effective relationship of the second CA-axis with the main trophic descriptors makes it possible to ordinate the phytoplankton taxa along a trophic gradient. In figure 8 the dominant phytoplankters listed in table 3 were ranked using their coordinates on the second-CA axis. The most striking features of figure 8 are the high eutrophic character of the Chlorophyceae (Chlorococcales, Pandorina and Carteria), and the high 

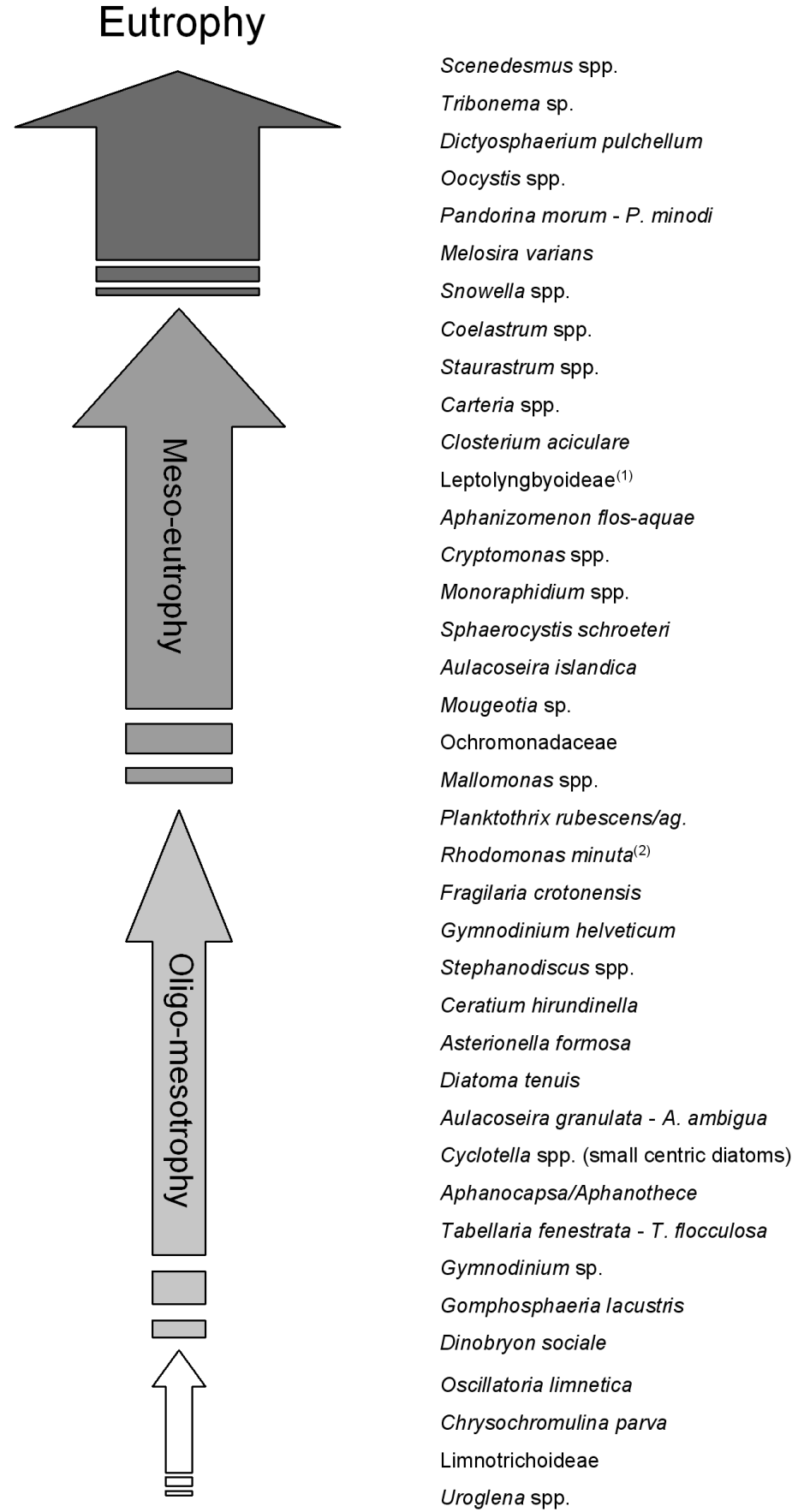

\section{Oligotrophy}

Fig. 8. Ordination of the phytoplankton taxa along the trophic gradient, from oligotrophy to eutrophy. Further explanations in the text. (1) Mainly Planktolyngbya limnetica; (2) including R. minuta v. nannoplanctica.

dispersion of the cyanobacteria along the trophic spectrum. Both Snowella colonies, the Leptolyngbyoideae (mainly P. limnetica) and Aphanizomenon flos-aquae score high along the trophic gradient, whereas $P$. rubescens/ag. confirms its status as a typical mesotrophic species restricted to the medium P-range (Sommer 1986; Lampert \& Sommer 1997). The colonies of Aphanocapsa/Aphanothece and Gomphosphaeria, along with Oscillatoria limnetica and the Limnotrichoideae
(Limnothrix sp.) score low along the trophic gradient. Mougeotia sp. is located in the mesotrophic range, whereas Closterium aciculare and Staurastrum spp. appear to indicate more eutrophic conditions. Some filamentous centric diatoms appear to have adapted to higher ( $M$. varians) or medium (A. islandica) trophic levels. The remaining centric diatoms and the pennates locate around the meso-oligotrophic range. The chrysophytes rank at the lower border of meso-eutrophy 
(Ochromonadaceae and Mallomonas spp.) or in the oligotrophic range (D. sociale and Uroglena spp.), as in the case of the haptophyte C. parva. C. hirundinella and $G$. helveticum, and Cryptomonas spp. rank around the oligo-mesotrophic and meso-eutrophic zone of the trophic gradient, respectively.

Caution should be taken when interpreting figure 8 for at least three reasons. Firstly, with increasing or decreasing trophic state, phytoplankton in the DSL may follow different changes in the community structure (cf. the differences in the geographic distribution of some species in table 4). Secondly, species with a more homogeneous distribution in lakes with different trophic levels are located closer to the horizontal line at ordinate zero in figure $7 \mathrm{~b}$. These species, which may be classified as "mesotrophic", are better adapted to different trophic levels than species located at the extremes of the trophic gradient; in this particular case, tolerance to different trophic conditions tends to increase towards the middle of the trophic spectrum. Finally, great caution should be taken in the case of taxa which are taxonomically uncertain or awaiting confirmation (e.g., Limnotrichoideae and Snowella spp.).

In many respects, the classification scheme of figure 8 is in good agreement with the trophic "preferences" assigned to the functional groups and species of phytoplankton by Reynolds $(1996 ; 1997)$ and Reynolds et al. (2002). This is the case of some species typical of eutrophy (C. aciculare, Cryptomonas spp., numerous Chlorococcales), mesotrophy ( $P$. rubescens, $A$. islandica) or oligotrophy (Cyclotella spp., D. sociale and Uroglena sp.). However, a few evaluations reported in the papers cited above do not agree with the observations made in the DSL, as these evaluations seem to overestimate the trophic character of some taxa (i.e. Asterionella, Fragilaria, A. granulata, Aphanothece, Aphanocapsa and Ceratium). This suggests that the trophic character of some algal associations should be reconsidered for this peculiar typology of lakes; it should also be stressed that the conspicuous presence of these species, if not followed by a substantial contribution of other indicator taxa, does not necessarily indicate eutrophic conditions.

The ordination of the lakes by CA exhaustively reflects their mutual relationships based on the phytoplankton biovolume peaks. However, a satisfactory interpretation of the species distribution was possible only along the second axis, which was strongly correlated with the majority of the environmental variables. The absence of any association of the first axis with the watershed and trophic variables (cf. Fig. 2, and Tabs 2, 5) means that the causes determining the differences observed between the E (Garda and Iseo) and the W (Lugano and Maggiore) lakes are still unresolved. However, the major differences seem to be between Lake Lugano and lakes Garda, Iseo and, partly, Como (Fig. 7a); some similar peculiarities in the $\mathrm{W}$ lakes may be explained by the fact that Lago Maggiore receives the waters of Lake Lugano via the River Tresa. Without experimental work, it is difficult to ascertain the real impact on the phytoplankton community of Lago Maggiore of viable populations of specific taxa coming from Lake Lugano. On the other hand, the synchronism in the appearance of some specific taxa (e.g., Tabellaria in 1999; Fig. 5e) in both lakes, or the sporadic presence of species typical of the more eutrophic Lake Lugano in the oligotrophic waters of Lago Maggiore (Aphanizomenon flos-aquae), suggest a significant involvement of inocula (e.g., viable cells or akinetes) in the simultaneous occurrence of some species in these two waterbodies. These considerations help only to explain the origin of some peculiarities shared by lakes Lugano and Maggiore.

An attempt to detect the ultimate causes of the differences observed between Lake Lugano and lakes Garda, Iseo and, partly, Como should take account of other different temporally and spatially scaled factors not discussed in this study. In particular, the food-web interactions have been considered an important element in the organization of the phytoplankton community in Lago Maggiore (Manca \& Ruggiu 1998). The importance of the internally generated population and community interactions (autoecology, predation, competition, parasitism) in the origin and structure of pelagic communities has been underlined, among others, by Harris (1994). In particular, Harris questioned the possibility of predicting the occurrence of species without taking the higher level interactions into account. Finally, a better understanding of the distribution of the different species in the subalpine lake district should also carefully consider the differences existing in the local climate, hydrological regimes and the intensity and frequency of the seasonal inputs of nutrients from the rivers.

\subsection{The historical factor}

As emphasised in section 4.3, the modifications observed in the phytoplankton structure during the last 50 years in response to the changes in the trophic states are such that the distribution and seasonal patterns described in this work may be considered valid for the lakes in their present conditions.

Among the deep southern subalpine lakes, Lago Maggiore is a distinctive case of recovery from eutrophication, and represents a paradigmatic example of good water resource management. The main steps of its trophic evolution have been described in many papers (see references in Morabito et al. 2002). Of those dealing with phytoplankton traits, that by Ruggiu et al. (1998) is the first to analyse in detail the evolution of the basic phytoplankton characteristics during the long term oligotrophication of the lake. This paper, which mainly focused on features describing the phytoplankton as a whole (numbers, biovolume, cell size, chloro- 
phyll- $a$, species richness), identified two phases of the oligotrophication process. During the first, stable phase (1978-1987), no significant changes took place in the phytoplankton structure despite a sensible reduction of in-lake phosphorus concentration. The second phase (1988-1995) was characterised by notable changes, among which the increase of biodiversity, the reduction of biovolume and the decrease of average community cell size were most prominent: these trends still characterise the Lago Maggiore phytoplankton.

Changes in the community characteristics during the last two decades have been both quantitative and qualitative. The first of these consists mainly in the biovolume reduction of a persistent pool of (mostly) large species, always dominant across the years in spite of the phosphorus reduction: the most important are $A$. formosa, F. crotonensis, A. islandica morf. helvetica, $C$. comensis, $P$. rubescens, $C$. hirundinella. All these species tolerate a wide spectrum of trophic conditions, according to the ranking in figure 8 .

The qualitative changes must be ascribed to those species whose development and decline are closely related to the trophic changes: Synedra acus, M. varians, Stephanodiscus alpinus and Microcystis aeruginosa were important during the first phase of stability, and during the shift towards oligotrophy were followed by the gradual development of Aphanothece spp., C. parva, many new small centric diatoms, Gomphosphaeria (Snowella) lacustris, O. limnetica and some Limnothricoideae. The increase of smaller sized species which started in the late 1980s has been partly responsible for the general decrease of community cell size.

An analysis of the changes in species composition has also made it possible to recognize a transition phase (1987-1990), during which the first signs of the recent trends were manifest: in those years many species tried to exploit the new opportunities offered by the changing environment, but few of them were able to establish stable populations. The most important were Mougeotia sp., which characterized - though with low biovolumes in the recent period (Tab. 2) - the phytoplankton of Lago Maggiore during the 1990s, and T. flocculosa, very common since the late 1990 s.

Though based on fewer observations and studies, the historical records of phytoplankton in Lake Garda document the strong impact of eutrophication on the phytoplankton community (Salmaso 2002). The most significant modifications of the pristine oligotrophic conditions in the $1970 \mathrm{~s}$ were the development of $P$. rubescens/ag. and the irregular increase of Conjugatophyceae (Mougeotia sp. and C. aciculare). During the 1980 s, the increase of phosphorus concentrations in the lake and the progress towards more mesotrophic conditions were accompanied by the appearance of new, dense populations of cyanobacteria ( $P$. limnetica, $A$. lemmermannii). In contrast with these signs of alteration, $F$. crotonensis, A. formosa, C. hirundinella and
Dinobryon spp. have been among the most abundant taxa from the 1950s to the present. On the basis of these observations it was possible to clarify the trophic features of the dominant species in Lake Garda. Besides the group of eurytrophic species ( $F$. crotonensis, $A$. formosa, C. hirundinella, Dinobryon spp.), P. rubescens/ag. and Mougeotia sp. became dominant at the start of oligo-mesotrophy, whereas Closterium spp., $P$. limnetica and $A$. lemmermannii seemed to indicate higher trophic conditions.

The changes observed in these two lakes in the rearrangement of the structure of the phytoplankton communities along historical trophic gradients are fully consistent with the trophic rank of the species reported in figure 8 , which is based on the trophic differences currently existing among the deep southern subalpine lakes.

The historical changes recorded in Lake Lugano are more difficult to interpret, due to the consistently high trophic state that has characterised this lake since the 1950s. However, the strong reduction of TP recorded in the last two decades in the $0-100 \mathrm{~m}$ layer (from 145 to the current 50-70 $\mu \mathrm{g} \mathrm{P} \mathrm{l}^{-1}$; Simona 2003) has been followed by a significant recent reduction in biomass, coupled with a decrease of $P$. rubescens and Stephanodiscus hantzschii (Polli \& Simona 1992; Barbieri \& Simona 1997).

In lakes Iseo and Como the information is more scattered and has been critically summarised in Garibaldi et al. (1995), Bettinetti et al. (2000) and Buzzi (2002).

\section{CONCLUSIONS}

The research carried out during the second half of the 1990s (Buzzi 2002; Morabito et al. 2002; Salmaso 2002; Garibaldi et al. 2003; Simona 2003) confirmed the existence of a common pool of species developing in the deep southern subalpine lakes Garda, Iseo, Como, Lugano and Maggiore (Ruggiu 1983; Ruggiu \& Mosello 1984; Salmaso 2000). The species belonging to this common pool, however, showed a different development along two environmental gradients, namely a trophic gradient, and a geographic gradient.

i) Some species were characterised by high interannual variability and/or high asymmetry in their geographic distribution. Two types of lakes were recognised on the basis of the first characteristic. The community of Lake Garda was described as being one of the best examples of year to year similarity in distribution and composition of phytoplankton in deep lakes. In contrast, the studies carried out on lakes Lugano and Iseo revealed the existence of a high degree of interannual variability, with seasonal cycles occurring only at the level of the main taxonomic groups. Conditions in Lago Maggiore seemed to be intermediate between these two extremes, whereas there emerged a strong need for more information for a robust evaluation of the interannual 
variability of phytoplankton in Lake Como. As for geographic distribution, the major differences in the phytoplankton were found between the eastern lakes (Garda and Iseo) and the western ones (Lugano and, partly, Maggiore), with intermediate characteristics in Lake Como. However, the chief differences among the lakes were due to changes in the dominance relationships among the constituent taxa and only secondarily to compositional changes. It was possible to recognise common patterns in the replacement of the seasonal assemblages, which were mainly represented by large diatoms during spring, and by more diversified and changing phytoplankton groups during the warmest months.

ii) The simultaneous ordination of the DSL and phytoplankton by Correspondence Analysis confirmed the positioning of the different species along the geographic gradient, underlining the separation of the $\mathrm{E}$ and $\mathrm{W}$ lakes. In fact the analysis clearly revealed a second gradient, which was correlated with the trophic descriptors (chlorophyll- $a$, phytoplankton biovolume and TP) and with many other environmental variables (conductivity, $\mathrm{Si}$, alkalinity and $\mathrm{pH}$ ). Consequently, a satisfactory interpretation of the ordination of lakes and species was possible along the trophic gradient. On the other hand, the absence of any association of the geographic gradient with the variables describing the watershed and/or the trophic characteristics did not help to identify the causes of the differences in the dominance relationships observed between the E (Garda and Iseo) and W lakes (Lugano and, partly, Maggiore). It was stressed that the detection of the ultimate causes of these differences should take into account other factors not considered in this work (i.e. specific analysis of food webs, local climatic conditions, hydrology and seasonal input of nutrients).

iii) The identification by Correspondence Analysis of a gradient strongly correlated with the trophic descriptors enabled the phytoplankton taxa to be ranked along a trophic spectrum (Fig. 8). The study revealed the highly eutrophic character of numerous Chlorococcales, Pandorina and Carteria, and the high dispersal of the cyanobacteria along the trophic gradient. P. limnetica and Aphanizomenon flosaquae were representative of more eutrophic conditions, whereas $P$. rubescens/ag. confirmed its status as a typical mesotrophic species. The colonies of Aphanocapsa/Aphanothece and Gomphosphaeria, along with Oscillatoria limnetica and the Limnotrichoideae, were typical of less eutrophic conditions. The conjugatophytes seemed to be better adapted to mesotrophic (Mougeotia sp.) or mesoeutrophic (C. aciculare, Staurastrum spp.) conditions. A few centric diatoms ( $M$. varians and, to a lesser extent, $A$. islandica) were probably adapted to higher trophic levels. The remaining centric diatoms and the large pennates were positioned around the meso-oligotrophic range. The chrysophytes were present at the lower border of meso-eutrophy (Ochromonadaceae and Mallomonas spp.) or in the oligotrophic range (D. sociale and Uroglena spp.).

Finally, in view of the marked changes observed since the 1950s in the phytoplankton community of the DSL, initially in response to the progress of eutrophication in the 1960's and 1970's and then as a result of the contrasting events linked to the generalised attempts to achieve environmental recovery in recent decades, the reported results should remain representative for the lakes in their present trophic condition. It is notable, however, that similarities are recognisable among the phytoplankton communities not only in the present situation but also, to a lesser extent, in comparison to much earlier times. From a practical point of view, a brief examination of the historical changes arising in the phytoplankton of some selected lakes with the progress of eutrophication shows the increasing importance of species identified in this study as being indicative of rather eutrophic conditions.

\section{REFERENCES}

Ambrosetti, W. \& L. Barbanti. 1992. Physical limnology in Italy: an historical review. Mem. Ist. ital. Idrobiol., 50: 3759.

Ambrosetti W. \& L. Barbanti. 1997. Alcune problematiche fisiche dei grandi laghi sudalpini. Documenta Ist. ital. Idrobiol., 61: 3-18.

Anagnostidis, K. \& J. Komárek. 1988. Modern approach to the classification system of Cyanophytes. 3-Oscillatoriales. Arch. Hydrobiol., Algol. Stud., 50-53: 327-472.

Barbieri, A. \& R. Mosello. 1992. Chemistry and trophic evolution of Lake Lugano in relation to nutrient budget. Aquatic Sciences, 54: 219-237.

Barbieri, A. \& B. Polli (Eds). 1992. Limnological aspects and management of Lago di Lugano. Aquatic Sciences, 54: $390 \mathrm{pp}$.

Barbieri, A. \& M. Simona. 1997. Trophic evolution of Lake Lugano following recovery intervention. Documenta Ist. ital. Idrobiol., 61: 73-91.

Barbieri, A. \& M. Simona. 2001. Recent trophic evolution of Lake Lugano related to external load reduction: changes in phosphorus and nitrogen as well as oxygen balance and biological parameters. Lakes \& Reservoirs: Research and Management, 6: 37-47.

Bettinetti, R., G. Morabito \& A. Provini. 2000. Phytoplankton community as indicator of the recent trophic and biological evolution of the western basin of Lake Como (N. Italy). Hydrobiologia, 435: 177-190.

Bonomi, G., A. Calderoni \& R. Mosello. 1979. Some remarks on the recent evolution of the deep italian subalpine lakes. Symp. Biol. Hung., 19: 87-111.

Buzzi, F. 2002. Phytoplankton assemblages in two sub-basins of Lake Como. J. Limnol., 61: 117-128.

de Bernardi, A. Calderoni \& R. Mosello. 1996. Environmental problems in Italian lakes, and lakes Maggiore and Orta as successful examples of correct management leading to restoration. Verh. int. Ver. Limnol., 26: 123-138.

de Bernardi, R., M. Gatto, R. Mosello \& L. Segre (Eds). 2000. Atti della Giornata di Studio 4: I laghi come risorsa per lo sviluppo. Politecnico di Milano, Consiglio Regionale della Lombardia, CNR-Istituto Italiano di Idrobiologia \& Asso- 
ciazione ex Consiglieri Regionali della Lombardia: 249 pp.

Garibaldi, L., M.C. Brizzio, V. Mezzanotte, A. Varallo \& R. Mosello, 1995. The continuing evolution of Lake Iseo (N. Italy): the appearance of anoxia. Mem. Ist. ital. Idrobiol., 53: 191-212.

Garibaldi, L., A. Anzani, A. Marieni, B. Leoni \& R. Mosello. 2003. Studies on the phytoplankton of the deep subalpine Lake Iseo. J. Limnol., 62(2): 177-189.

Garibaldi, L., V. Mezzanotte, M.C. Brizzio, M. Rogora \& R. Mosello. 1999. The trophic evolution of Lake Iseo as related to its holomixis. J. Limnol., 58(1): 10-19.

Harris, G.P. 1994. Pattern, process and prediction in aquatic ecology. A limnological view of some general ecological problems. Freshwat. Biol., 32: 143-160.

Humbert, J.F. \& B. Le Berre. 2001. Genetic diversity in two species of freshwater cyanobacteria, Planktothrix (Oscillatoria) rubescens and P. agardhii. Arch. Hydrobiol., 150: 197-206.

Hutchinson, G. E.. 1967. A treatise on limnology. 2. Wiley \& Sons, New York: $1115 \mathrm{pp}$

Komárek, J. \& K. Anagnostidis. 1999. Cyanoprocariota. 1 Teil: Chroococcales. Süßwasserflora von Mitteleuropa. Band 19/1. Gustav Fisher, Jena: 548 pp.

Krebs, C.J., 2001. Ecology. 5th edn, Addison-Wesley, San Francisco: $695 \mathrm{pp}$.

LSA (Laboratorio Studi Ambientali) - SPAA. 1995. Ricerche sull'evoluzione del Lago di Lugano. Aspetti limnologici. Programma quinquennale 1993-1997. Campagna 1995. Commissione internazionale per la protezione delle acque italo-svizzere (ed.): $100 \mathrm{pp}$.

Lampert, W. \& U. Sommer. 1997. Limnoecology: the ecology of lakes and streams. Oxford-University-Press-Incorporated, New York: 382 pp.

Manca, M. \& D. Ruggiu. 1998. Consequences of pelagic foodweb changes during a long-term lake oligotrophication process. Limnol. Oceanogr., 43: 1368-1373.

Manca, M., A. Calderoni \& R. Mosello. 1992. Limnological research in Lago Maggiore: studies on hydrochemistry and plankton. Mem. Ist. ital. Idrobiol., 50: 171-200.

Manca, M., N. Cavicchioni \& G. Morabito. 2000. First observations on the effect of a complete, exceptional overturn of Lake Maggiore on plankton and primary production. Internat. Rev. Hydrobiol., 85: 209-222.

Micheletti, S., F. Schanz \& A.E. Walsby. 1998. The daily integral of photosynthesis by Planktothrix rubescens during summer stratification and autumnal mixing in Lake Zurich. New Phytol., 139: 233-246.

Moccia, A., F. Decet \& N. Salmaso. 2000. Plankton and nutrient evolution of a Piedmont reservoir in Northern Italy (L. Santa Croce). Verh. int. Ver. Limnol., 27: 2929-2933.

Morabito, G. 2001. Relationships between phytoplankton dynamics in Lake Maggiore and local climate in the period 1978-'98. Atti Ass. Ital. Oceanol. Limnol., 14: 147-156.

Morabito, G. \& A. Pugnetti. 2001. Primary productivity and related variables in the course of the trophic evolution of Lake Maggiore. Verh. int. Ver. Limnol., 27: 2934-2937.

Morabito, G., D. Ruggiu \& P. Panzani. 2002. Recent dynamics (1995-1999) of the phytoplankton assemblages in Lago Maggiore as a basic tool for defining association patterns in the Italian deep lakes. J. Limnol., 61: 129-145.

Morabito, G., A. Oggioni \& P. Panzani. (2003). Phytoplankton assemblage at equilibrium in large and deep subalpine lakes: a case study from Lago Maggiore (N. Italy). Hydrobiologia, 502: 12 pp. (in press).

Mosello, R. 1983. Caratteristiche chimiche dei laghi profondi sudalpini. In: W. Ambrosetti, L. Barbanti, R. Mosello, A. Rolla \& D. Ruggiu (Eds), Mescolamento, caratteristiche chimiche, fitoplancton e situazione trofica nei laghi profondi sudalpini. C.N.R.-P.F. Promozione della Qualità dell'Ambiente, AQ/2/20: 71-104.
Mosello, R. \& D. Ruggiu. 1985. Nutrient load, trophic conditions and restoration prospects of Lake Maggiore. Int. Rev. ges. Hydrobiol., 70: 63.75.

Mosello, R. \& G. Giussani (Eds). 1997. Evoluzione recente della qualità delle acque dei laghi profondi sudalpini. Documenta Ist. ital. Idrobiol. 61: $228 \mathrm{pp}$.

Mosello, R., D. Ruggiu, A. Pugnetti \& M. Moretti. 1991. Observed trends in the trophic conditions and possible recovery of the deep subalpine Lake Como (Northern Italy). Mem. Ist. ital. Idrobiol., 49: 79-98.

Mosello, R., M.C. Brizzio, F. Buzzi, L. Colzani, E. Pizzotti \& D. Mocellin. 2001. Qualità delle acque dei tributari e del Lario nel biennio 1998-1999. Atti Ass. Ital. Oceanol. Limnol., 14: 137-146.

Mosello, R., M.C. Brizzio, L. Garibaldi, F. Buzzi, L. Colzani, E. Pizzotti \& D. Mocellin, 1999. Attuali condizioni trofiche dei bacini di Como e Lecco del Lario. Acqua \& Aria, 9: 71-81.

OECD. 1982. Eutrophication of waters. Monitoring, assessment and control. OECD, Paris: $154 \mathrm{pp}$.

Padisák, J., Ė Soróczki-Pintér \& Z. Rezner. 2003. Sinking properties of some phytoplankton shapes and the relation of form resistance to morphological diversity of plankton - an experimental study. Hydrobiologia, 500: 243-257.

Polli, B. \& M. Simona. 1992. Qualitative and quantitative aspects of the evolution of the planktonic populations in Lake Lugano. Aquat. Sci., 54: 303-320.

Pollingher, U. 1990. Effects of latitude on phytoplankton composition and abundance in large lakes. In: Tilzer, M.M. \& C. Serruya (Eds), Large Lakes. Ecological structure and function. Springer Verlag, Berlin: 368-402.

Reynolds, C.S. 1996. The plant life of the pelagic. Verh. int Ver. Limnol., 26: 97-113.

Reynolds, C.S. 1997. Vegetation processes in the pelagic: a model for ecosystem theory. Ecology Institute, Oldendorf: $371 \mathrm{pp}$.

Reynolds, C.S., V.L.M. Huszar, C. Kruk, L. Naselli-Flores \& S. Melo. 2002. Towards a functional classification of the freshwater phytoplankton. J. Plankton Res., 24: 417-428.

Ruggiu, D. 1983. Caratteristiche e comportamento del fitoplancton nei laghi profondi sudalpini. In: W. Ambrosetti, L. Barbanti, R. Mosello, A. Rolla \& D. Ruggiu (Eds), $\mathrm{Me}$ scolamento, caratteristiche chimiche, fitoplancton e situazione trofica nei laghi profondi sudalpini. C.N.R.-P.F. Promozione della Qualità dell'Ambiente, AQ/2/20: 105143.

Ruggiu, D. 1989. An evaluation of phytoplankton communities of Lago Maggiore typifying the stages of its trophic evolution. Mem. Ist. ital. Idrobiol., 46: 89-102.

Ruggiu, D. 2002. Phytoplankton in deep Italian lakes: introductory remarks. J. Limnol., 93-94.

Ruggiu, D. \& R. Mosello. 1984. Nutrient levels and phytoplankton characteristics in the deep southern alpine lakes. Verh. int. Ver. Limnol., 22: 1106-1112.

Ruggiu D., G. Morabito, P. Panzani \& A. Pugnetti. 1998. Trends and relations among basic phytoplankton characteristics in the course of the long-term oligotrophication of Lake Maggiore (Italy). Hydrobiologia, 369/370: 243-257.

Salmaso, N. 1996. Seasonal variation in the composition and rate of change of the phytoplankton community in a deep subalpine lake (Lake Garda, Northern Italy). An application of nonmetric multidimensional scaling and cluster analysis. Hydrobiologia, 337: 49-68.

Salmaso, N. 2000. Factors affecting the seasonality and distribution of cyanobacteria and chlorophytes: a case study from the large lakes south of the Alps, with special reference to Lake Garda. Hydrobiologia, 438: 43-63.

Salmaso, N. 2002. Ecological patterns of phytoplankton assemblages in Lake Garda: seasonal, spatial and historical features. J. Limnol., 61: 95-115. 
Salmaso, N. (2003). Life strategies, dominance patterns and mechanisms promoting species coexistence in phytoplankton communities along complex environmental gradients. Hydrobiologia, 502: (in press).

Salmaso N. \& F. Decet. 1998. Interactions of physical, chemical and biological processes affecting the seasonality of mineral composition and nutrient cycling in the water column of a deep subalpine lake (Lake Garda, Northern Italy). Arch. Hydrobiol., 142: 385-414.

Salmaso, N., F. Decet \& R. Mosello. 1997. Chemical characteristics and trophic evolution of the deep subalpine Lake Garda (Northern Italy). Mem. Ist. ital. Idrobiol., 56: 51-76.

Salmaso, N., G. Franzini \& P. Cordella, 2001b. Evoluzione pluriennale delle caratteristiche chimiche e del fitoplancton nel Lago di Garda. XI Congresso Nazionale della Società italiana di Ecologia, Sabaudia, 12-14 settembre 2001, Atti 25. Edizione CD-ROM, ISSN 1127-5006: 14 pp.

Salmaso, N., F. Decet \& P. Cordella. 2002. Spring mixing depth affects the interannual variations in phytoplankton abundance and composition in deep lakes. A case study from Lake Garda (Northern Italy). Verh. int. Ver. Limnol., 28: 1486-1489.

Salmaso, N., F. Decet, G. Franzini \& P. Cordella. 2001a. Evoluzione trofica del Lago di Garda in relazione alla completa circolazione delle acque del 1999 e 2000. Atti Ass. Ital. Oceanol. Limnol., 14: 109-123.

Salmaso, N., R. Mosello, L. Garibaldi, F. Decet, M.C. Brizzio \& P. Cordella. 2003. Vertical mixing as a determinant of trophic status in deep lakes: a case study from two lakes south of the Alps (Lake Garda and Lake Iseo). J. Limnol., 62 (Suppl. 1): 33-41.
Simona, M. 2003. Winter and spring mixing depths affect the trophic status and composition of phytoplankton in the northern meromictic basin of Lake Lugano. J. Limnol., 62(2): 190-206.

Sommer, U., 1986. The periodicity of phytoplankton in Lake Constance (Bodensee) in comparison to other deep lakes of central Europe. Hydrobiologia, 138: 1-7.

Sommer, U. 1987. Factors controlling the seasonal variation in phytoplankton species composition. A case study for a deep, nutrient rich lake. Prog. Phyc. Res., 5: 123178.

Sommer, U. 1988. Growth and survival strategies of planktonic diatoms. In: Sandgren, C.D. (Ed.), Growth and reproductive strategies of freshwater phytoplankton. Cambridge University Press, Cambridge: 227-260.

StatSoft. 1997. StatisticaTM for Windows. (Volume III): Statistics II, 2nd Edition. StatSoft Inc., Tulsa, OK: 30013782 .

Stenson, H. \& L. Wilkinson. 2002. Factor Analysis. In: Systat TM 10.2 Statistics I. Systat Software Inc., Richmond, CA: 327-363.

Systat. 2002. Systat TM 10.2 Statistics I and II. Systat Software Inc., Richmond, CA.

Vollenweider, R.A. 1965. Materiali ed idee per una idrochimica delle acque insubriche. Mem. Ist. ital. Idrobiol., 19: 213-286.

Watson, S.B., E. McCauley \& J.A. Downing. 1997. Patterns in phytoplankton taxonomic composition across temperate lakes of differing nutrient status. Limnol. Oceanogr., 42: 487-495.

Wilson, E.O. 1992. The diversity of life. Penguin Books, London: $406 \mathrm{pp}$. 